\title{
Science, stigmatisation and afro-pessimism in the South African debate on AIDS'
}

\author{
Guillermo Vega Sanabria \\ Department of Social Science, Federal University of Viçosa², Viçosa/MG, Brazil
}

\section{Summary}

This paper examines how certain assumptions concerning sexual behaviour, race and nationality emerge at the core of explanations regarding the origin of HIV. In particular, it returns to discussions of the so-called "AIDS debate" in South Africa in the 20oos. On the one hand, it focuses on how these assumptions reinforce the understanding of AIDS as stigma and "social problem", to the extent that they emphasise the existence of geographical areas and "risk groups". On the other, these same assumptions are examined in the light of processes of identification and belonging, given that in the majority of reports, both academic and popular, "Africans" and "Africa" are inexorably understood in pessimistic terms. The purpose is to show how certain aspects of the South African debate refer to the way the global history of AIDS has been constructed over the past three decades. An exhaustive historiographical reconstruction is not attempted here, rather by returning to some works on the genesis of the epidemic, the paper highlights the individual and collective stigmatisation related to the public health discourse on AIDS, particularly such notions as "risk", "exposure" and "vulnerability". The proposal is such notions are strongly informed by a moral sense that traverses the dominant cognitive model in the approaches to the global epidemic and the AIDS debate in South Africa. The last part of the article focuses on the tensions that emerge between the explanations of experts from the field of public health and the contributions of social scientists, particularly anthropologists, frequently questioned for their alleged cultural relativism.

Keywords: HIV/AIDS in South Africa, Scientific controversies, HIV/AIDS and anthropology

\footnotetext{
1 The first part of the article is based on the communication Questões preliminares para uma etnografia da controvérsia científica sobre a origem da AIDS [Preliminary questions for an ethnography of the scientific controversy concerning the origin of AIDS], presented by Working Group 44: Ethnographic translations: Anthropology and Science, at the VIII Mercosur Anthropology Meeting (2009). The work corresponds to a modified version of the third chapter of my doctoral thesis, entitled Ciência, justiça e cultura na controverrsia sul-africana sobre as causas e tratamentos da AIDS [Science, justice and culture in the South African controversy on the causes and treatments of AIDS] (PPGAS/ Museu Nacional/UFRJ, 2013). I am grateful to the editor Peter Fry and two anonymous reviewers for their valuable suggestions.

2 Assistant Professor of the Department of Social Sciences of the Federal University of Viçosa, Brazil.
} 


\section{Resumo}

Este trabalho examina como certos pressupostos sobre comportamento sexual, raça e nacionalidade surgem no âmago das explicações e contra-explicações acerca da origem do HIV. Ele retoma, em particular, algumas discussões e dados etnográficos do que ficou conhecido como o "debate da AIDS", ocorrido na África do Sul na década de 2000. $O$ artigo enfoca, por um lado, o modo como esses pressupostos produzem e reforçam a compreensão da AIDS como estigma, desvio e problema social, uma vez que enfatizam a existência de áreas geográficas e grupos de risco. Por outro, esses mesmos pressupostos são examinados à luz de processos de identificação, pertencimento e formas de espacialização, à medida que na maior parte dos relatos, tanto acadêmicos como populares, "africanos" e "África" são compreendidos implacavelmente em termos pessimistas.

O objetivo é mostrar como alguns traços do debate sul-africano remetem ao modo como a história global da AIDS foi construída nas últimas três décadas. Não é feita aqui uma reconstrução historiográfica exaustiva, mas, ao retomar algumas pesquisas sobre a gênese da epidemia, chama-se a atenção para a estigmatização individual e coletiva atreladas à produção do discurso da saúde pública sobre a AIDS, especialmente a partir de noções como "risco", "exposição" e "vulnerabilidade". Propõe-se que tais noções se acham fortemente embasadas num senso moral que atravessa o modelo cognitivo dominante nas abordagens da epidemia global e do debate da AIDS na África do Sul. A última parte do trabalho foca nas tensões que surgem entre as explicações de especialistas do campo da epidemiologia e da saúde pública e as preocupações dos cientistas sociais, especialmente os antropólogos, amiúde questionados pelo seu alegado relativismo cultural.

Palavras-chave: HIV/AIDS na África do Sul, Controvérsias científicas, HIV/AIDS e antropologia 


\title{
Science, stigmatisation and afro-pessimism in the South African debate on AIDS
}

\author{
Guillermo Vega Sanabria
}

\section{The weight of a (red) cross}

In late 2002, while walking in a shopping centre in Cali, Colombia, I came across Red Cross staff who were distributing pamphlets in the middle of a blood donation campaign. The pamphlets contained information for potential donors on when people are "at risk of contracting and transmitting the AIDS virus" 3 . This is because individuals "at risk" were prevented from donating blood. The situations of "risk" mentioned were:

1) Being a "man who had sex with another man from 1977 onwards, even if it was only once".

2) Having "injected an illegal drug, even if it was only once".

3) Having been "born or emigrated from Haiti or Africa and arrived in Colombia after 1977".

4) Having had or been treated for "diseases like syphilis or gonorrhoea in the last twelve months".

5) Having "had sex with a person who has any of the risks mentioned above, from 1977 onwards".

6) Being "a man or woman who has practiced prostitution at any time from 1977 onwards".

7) Having "had sex with someone who practices prostitution after 1977".

Caught by surprise by the list, I decided to talk to a doctor on the Red Cross staff on site to try to understand the reasons for some of these exclusions, for example, those based on national origin. Seeing my reluctance in the face of her explanations on "incidence" and "prevalence" and listening to my questions about the openly discriminatory character of the information provided in the pamphlets, annoyed, she ended the conversation by saying: "sir, I'm a doctor!".

Returning to the city in $\mathbf{2 0 0 7}$, I encountered other blood collection campaigns, with the same pamphlets being distributed. I decided to telephone the local Red Cross haematology centre, insisting on my concerns regarding these materials. Another doctor, this time with a more laid back attitude, offered me several arguments to justify the information contained in the pamphlets, all based on the idea of "risk groups", the "contagion risk" of HIV and the consequences of "sexual promiscuity". Realising the discomfort that her reasoning produced in me, she bluntly asked, "tell me something, do you have sex with other men? Do you have a stable sex life?". Finally, given the futility of my previous contacts, I wrote a letter to the director of the haematology centre. Since I received no response, I forwarded another letter to the regional director of the Red Cross asking for a pronouncement on the matter.

3 According to the UNAIDS Terminology Guidelines (2015, p. 5), "AIDS is a clinical syndrome. Thus, it is incorrect to refer to an AIDS virus". 
Figure 1: Pamphlet distributed during a blood donation campaign by the

Red Cross in Cali, Colombia, on $9^{\text {th }}$ of March, 2007

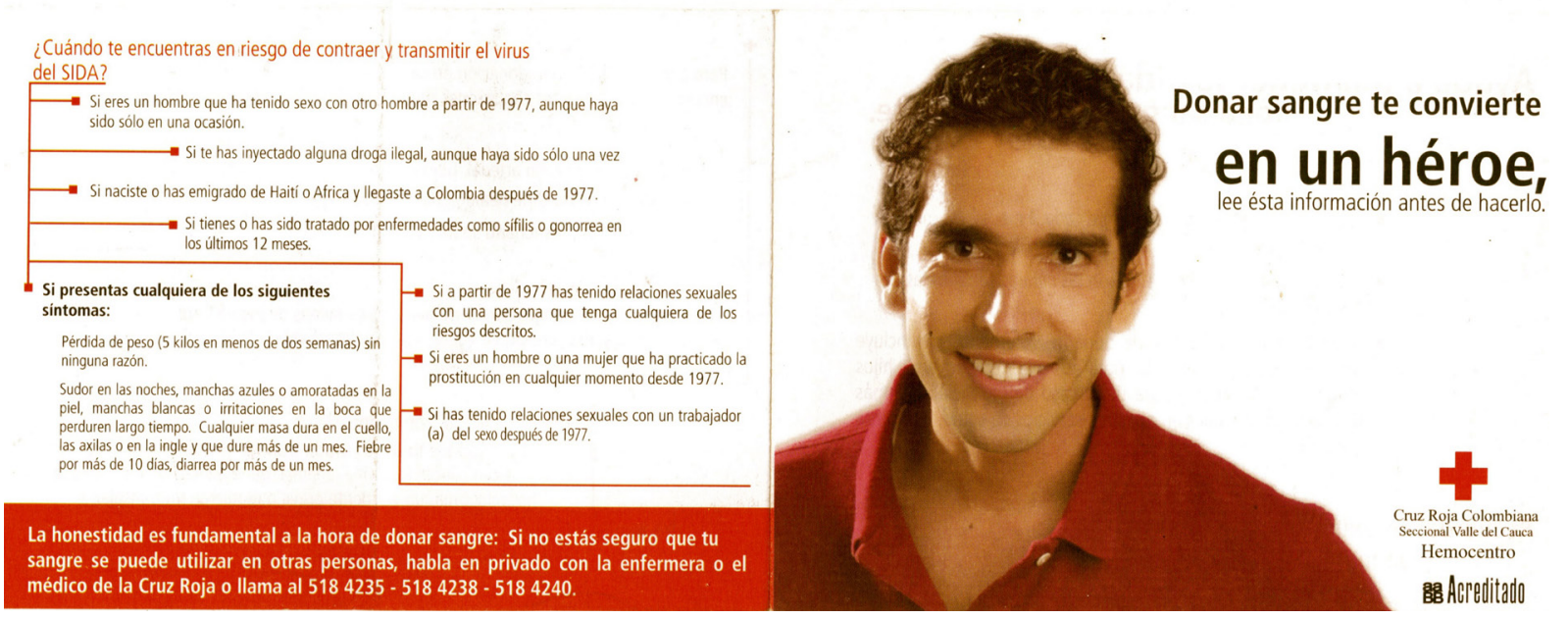

Two months after my first letter, I finally received a reply. In it, the medical director of the haematology centre claimed it was not the Red Cross that had "invented" the requirements for donating blood, but the Colombian Ministry of Health. According to him, they were "universal standards accepted by all health agencies in all nations because the disease is the same and the modes of transmission are the same all over the world". The medical director also stated that all blood banks had an "enormous responsibility" to provide "safe blood" to their patients (bold and italics as per the original) and it was necessary to "heighten all possible controls" for this purpose. In his words, "only the strict selection of donors can help prevent the transmission of an infectious disease" 4 . As for my request to modify the contents of the pamphlets, the doctor suggested that I forward this to the Ministry of Health, the entity that regulates compliance with the rules of blood banks in Colombia.

The last time I encountered a Red Cross pamphlet, in March 2008, the warnings about who "should not donate blood" had changed slightly. This time, there was no allusion to AIDS anywhere on the pamphlet; the front page had a photo of a black man smiling and no mention was made of the potential donor's place of residence or national origin. Although I never found out the official reason for this, I interpreted this change as a way of avoiding the explicit exclusion of "Haitians" and "Africans" as blood donors.

4 The UNAIDS Terminology Guidelines (2015, p. 4) advises that, "No one is infected with AIDS; AIDS is not an infectious agent. AIDS describes a syndrome of opportunistic infections and diseases that can develop as immunosuppression deepens along the continuum of HIV infection (from acute infection to death)". 
Figure 2: Pamphlet distributed during a Red Cross

blood donation campaign in Cali, Colombia, on March $28^{\text {th }}, 2008$

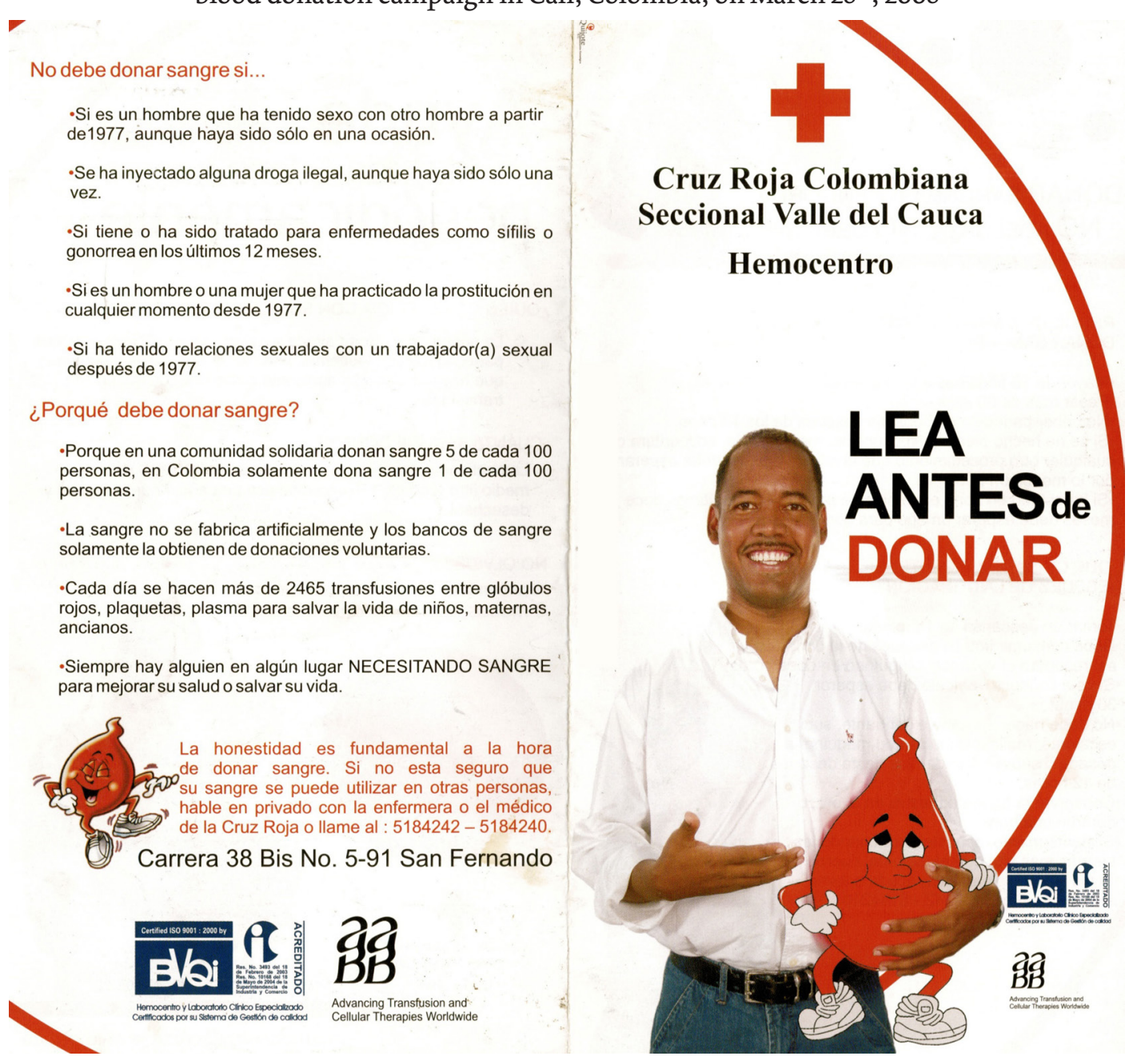

Incited by situations like this, I began to think more systematically on how well-intentioned messages — often brokered by prestigious incontestable institutions like the Red Cross—and widely accepted norms, like those established by a Ministry of Health, as well as news reports and inclusive academic discourses, reinforce the association made between diseases and certain human collectives.

In this article, I examine how arguments posed in discussions on the origin and transmission of HIV can be understood, in reference to Feldman's expression (2002, p. 235), by virtue of a "pathologisation" imposed on certain human collectives. This is because, although the idea that "HIV recognizes no social, political or geographic boundaries" seems to be a consensus ${ }^{5}$, the main issues related to the aetiology and natural history of AIDS (sex, intravenous drug use, blood and pregnancy) concern culturally sensitive categories. The controversy that occurred in South Africa in the 2ooos regarding the causes and treatment of AIDS seems to concentrate attention on these categories, introducing problems relating to the "specific manifestation of AIDS in the West" and the "specifically African incidence of HIV-AIDS", as stated in a letter from then President Thabo Mbeki to "world leaders" in 2000.

5 The Durban Declaration. 200o. Nature, 406: 15-16. Available at: <http://www.nature.com/nature/journal/v406/n6791/pdf/406o15ao.pdf >. Accessed on: 28 $8^{\text {th }}$ of June, 2007. 
Derived from a series of scientific and journalistic publications, I describe how assumptions regarding sexual behaviour, race and nation, themes central to the South African debate, are at the heart of the explanations and counter-explanations concerning the origin of AIDS. In this context, I draw attention to the way these discourses produce and reinforce the understanding of AIDS as stigma (Stephenson, 1991) and as social problem (Sayad, 1991), to the extent that they emphasise the existence of geographical areas and "risk groups", "vulnerable groups" or, more recently, "key populations"-notions narrowly associated with the epidemiological concepts of "incidence" and "prevalence".

I examine these issues in light of a more general phenomenon related to processes of identification, belonging and inclusive forms of spatialisation of nation states (Ferguson, 2006; Mbembe, 2000), since in the majority of reports, both academic and popular, "Africans" and "Africa" are understood in inexorably (afro-) pessimistic terms (Mbembe 2000). As Ferguson points out (2006, p. 8):

Africa is inevitably characterized by reference to a series of lacks, failures, problems, and crises. Its states are "weak," "poorly consolidated," "failed," and "dysfunctional"; its economies, "underdeveloped," "collapsing," and increasingly "marginal" to the world. Its people appear as victims many times over: victims of poverty, of war, and above all of AIDS - all the modern plagues that seem to have a kind of perverse affinity for the African continent. Such accounts can be rightly faulted for seeing Africa only in negative relation to normative standards ("proper states," "good economies," etc.) that are external to it.

AIDS, as Feldman also suggests (2002, p. 235), operates here as a "pathogenic stigma" which simply confirms the "geopolitical pathogenic character" of these emerging political zones.

\section{The dangerous other}

Upon completion of the first decade of the HIV epidemic, Clatts et al. (1991, p. 38) indicated that the discourse concerning risk groups for AIDS implicitly reflected a particular social construction of the idea of risk. For example, according to the initial conjecture, the morbidity and mortality of gay men in which the new epidemic had been identified was due to two of their behavioural characteristics: the (large) number of sexual partners and the use of poppers, both proposed as cofactors. The appearance of the disease in nonhomosexuals should have meant that this vision lost any justification. However, in the mid-1980s, the epidemic was popularly known as "the five-H disease", that of homosexuals, haemophiliacs, Haitians, heroin users and hookers.

Interestingly, the reactions to the first manifestations of AIDS appeared to simply modernise the original meaning of some terms related to it. Used by Hippocrates to classify diseases that affected a large proportion of the population, the word epidemic simultaneously referred to a social category. "Epidemos was the word used by the Greeks for people who lived outside the cities, but spent time in them and then left again. Those living in the cities were called Endemos. Thus, Hippocrates called epidemics those diseases that appeared suddenly and affected a large part of the population, were not typical of the area and that left after a while" (EPIDEMIAS, 2009, p. 13). Etymologically related to the word demmos, endemic refers to the idea of autochthonous, originating in a place; epidemic, however, refers to that which comes from outside, the stranger. From a modern point of view, a disease that is continually found in one area and affects a relatively small number of people is endemic. A pandemic, in contrast, is a widespread epidemic, which can affect entire continents or even the whole world ${ }^{6}$.

6 UNAIDS (2015, p. 10) recommends avoiding using the term "pandemic" because, depending on the circumstances, it could be inaccurate. According to the agency, it is always preferable to specify the size of the epidemic in question: local, national, regional or global. 
Based on these observations, I propose that expressions such as endemic disease and epidemic can be primarily considered as a social allegory of relationships with others. AIDS also remits this alterity, however, related to the "autre dangereux" to use the expression of Clatts and Mutchler (apud Clatts, Deren \& Tortu, 1991, p. 50; see also Schoepf, 2001, p. 340). The other is dangerous because she/he is a "carrier" of the disease and, therefore, inconvenient, as Clatts et al. (1991, p. 38) designated in the early years of AIDS.

Much of the discourse that emerged concerning members of "high risk groups" associated with the social and political process is implied, at least tacitly, in the development of metaphors of alterity (Clatts \& Mutchler, 1989). These are often made in idiomatic expressions that refer not only to individual failure, to evil and to inadequacy, but also to the collective irrationality, whose illicit sexual behaviour and drug use are often given as proof. Thus, being associated with AIDS has come to mean much more than just being affected by HIV; it also means being unclean, being unwanted, being unwelcome among others, being guilty and causing scandal and fear. And perhaps above all, having AIDS means deserving your illness...7

Considered in this manner, the construction of the "risk group" was settled from the outset and has reproduced existing stereotypes ever since. Such stereotypes not only operate as a "discursive weapon of power", insidious or ironic, but also through exaggerated performances in relation to others thus stereotyped (Herzfeld, 2004, p. 202). According to Herzfeld, in a particular kind of practical consciousness, the use of these forms of differentiation is directly related to the strength they possess, that is, to their power to affect and produce concrete consequences in people's lives.

Stigmatisation is, according to Stephenson in a pioneering work on AIDS, "[...] a process by which public opinion seizes an idea in a rapid and unbridled manner, such that critical thinking and the use of logical arguments for opposing this idea seem futile. Indeed, a little like the case of witchcraft, once a simple premise is accepted, the system becomes perfectly logical in itself" 11991, p. 92). According to the author, the processes of stigmatisation ensure that the people stigmatised embody both the responsibility for the ideological and social collapse that the stigma signifies, as well as the moral or divine punishment for such collapse. This dual role is the emblem of stigmatisation. It is metonymy and not metaphor, a trope through which individuals become symbols of their illness.

In view of this moral dimension of the disease and its stigmas, this goes beyond the restricted domain of a clinico-epidemiological problem and becomes a "social problem". I propose to address this aspect of stigmatisation following the reasoning of Abdelmalek Sayad (1991) regarding how the uniqueness of certain situations is socially recreated under the pretext of being merely recognised, named and even researched. The strangeness noted by Sayad in the presence of the eternal temporariness of the immigrant is useful for contemplating the creation of entities like "risk groups", "HIV-positive individuals", HIV "carriers"—and even

\footnotetext{
7 Original in French: «Une bonne partie du discours qui a émergé à propos de membres des "groupes à haut risque” associés au tant que processus social et politique, se trouvent, du moins tacitement, impliquées dans l'élaboration de métaphores de l’altérité (Clatts \& Mutchler, 1989). Ces dernières sont souvent formulées dans des expressions idiomatiques qui renvoient non seulement à l'échec individuel, au mal et à l'inadaptation, mais aussi à l'irrationalité collective, dont les comportements sexuels illicites et l'usage de drogue sont souvent donnés pour preuve. Ainsi, le fait d'être associé au sida en est venu à signifier beaucoup plus que d'être simplement affecté par le HIV; cela signifie aussi ne pas être propre, ne pas être désiré, ne pas être bienvenu parmi les autres, être coupable et susciter le scandale et la peur. Et peut-être par-dessus tout, avoir le sida signifie mériter sa maladie... » Clatts et al. (1991, p. 38)

8 Original in French: « [...] un processus par lequel l'opinion publique s'empare d’une idée de façon rapide et débridée, de telle sorte que la pensée critique et le recours à une argumentation logique pour s'opposer à cette idée semblent futiles. En effet, un peu comme dans le cas de la sorcellerie, une fois qu'une simple prémisse est acceptée, le système devient parfaitement logique en lui-même " (Stephenson, 1991, p. 92)
} 
more vague categories, in which the "risk", "exposure" or "seropositivity" are aggregated as ethnic/ethnicised/ national marks representative of, for example, "African", "Haitian", etc. What interests me here, above all, is to explore the normative framework - epistemological, moral, existential—within which these categories are produced, focusing on what might be the presupposition of an economic theory of the notion of risk.

When referring to the fallacy of the equation "immigration = unemployment", Sayad's analysis of Algerian immigration in France addresses the issue of risk and reveals the precarity of these associations: they are intellectually questionable, socially inaccurate, morally unjust and politically petty, because alone they suffice to produce and impose discredit (1991, p. 45-46).

Immigration, under the influence of several factors, had become established as a "social problem" before becoming the object of sociology. [...] More than any other social object, the discourse a propos the immigrant and immigration is an imposed discourse; moreover, the entire social science problematic of immigration is an imposed problematic [...] This pairing between a social group and a series of social problems constitutes the most evident indication that the research problematic, how it is commissioned and how it is conducted, is in conformity and in direct continuity with the social perception that exists of immigration and the immigrant...9 (1991, p. 62-63, emphasis in original).

However, the stigmatising discourse that creates the "risk groups" for AIDS is, in this context, paradoxically, the instrument that also allows the moral restitution of these dangerous classes. Rather than a contradiction, in the ambiguity of this discourse all the positivising strength of social relationships are perceived. While based on stereotypes, these categories are, as Herzfeld suggests (2004), a particular expression of certain "practical consciousness" in the flow of relationships, a mobilising attribute of social life. They are actuated as instruments of differentiation or reaffirmation of alterity, in that they exercise their power as a form of social control, for example, by their ability to morally restore those who had initially stigmatised. Thus, within a kind of dialectic of marginality, invoking risk enables the legitimisation of the vindications, practices, values and identity of the people affected by stigma. In the earliest moments of HIV, for example, Pollak and Schiltz (1987; 1991) described the adjustments experienced by French homosexuals in the wake of the new epidemic. Sivori (2007, p. 27) also described how the militant action of the Argentinian "homosexual movement", and experts linked to it, made use of the notion of "vulnerability" to support their demands for representation, emphasising the consequences of marginalisation and clandestine sex.

When faced with the novelty of AIDS, the apparently new medical and epidemiological discourse coincided with old ideological matrices and forms of social classification. In its most consummate version, categories like "risk group", "HIV-positive" and "endemic" are overlaid with an objectifying technical language that subordinates or denies their social origin and are framed as the logical and natural order of things. However, as Bibeau and Murbach have suggested, AIDS would simultaneously act as a révelateur, forcing the public revealing of that which usually tends to be hidden, and as inquiry by a large number of subjects, operating as science, which is constructed on our prejudices and fears, via the questioning of our sexual ethics (1991, p. 6-7).

9 Original in French: "L'immigration a fini, sous l'influence de différents facteurs, par être constituée en "problème social» avant de devenir l'objet de la sociologie. [...] Plus que tout autre objet social, il n'est de discours à propos de l'immigré et de l'mmigration qu'un discours imposé; plus que cela, c'est même toute la problematique de la science sociale de l'immigration qui est une problematique imposée [...] Cet appariement entre un groupe social et une série de problémes sociaux constitue l'indice le plus l'indice le plus manifeste que la problématique de la recherche, telle qu'elle est commanditée et menée, est en conformité et en continuité directe avec la perception sociale qu'on a de l'immigration et de l'immigré. » (Sayad, 1991, p. 62-63) 
Thus "an epidemic of signification" (Treichler, apud Schoepf, 2001, p. 338), the idea that the representations and practices of HIV/AIDS are framed in the social structures and modes of pre-existing thought, is not only true for lay people affected by the epidemic, but also for the communities of scientists that research it. The power to define the epidemic lies above all in the international biomedical community, but such definitions converge with representations and long-lasting practices regarding what a disease is, the notions of contagion and of a "disorderly" sexuality in the most affected populations, as shown in the discourse on the origin and propagation of HIV (Schoepf, 2001, p. 338).

\section{The AIDS Belt or Haiti-first}

Since the initial cases of what would later be called AIDS were registered in the United States in the 1980 , doctors and scientists have sought to understand how, when and where the mysterious virus, as currently established, causes the collapse of the immune system. Revealingly, the review that Pepin (2011) wrote of the explanations released since then, begins by affirming: "It is now thirty years since the discovery of AIDS but its origins continue to puzzle doctors and scientists". Some explanations were offered early on, including some that were frankly surprising, such as one that claimed it was of extraterrestrial origin (proposed by Sir Fred Hoyle and colleagues). It was also suggested that HIV was deliberately created as a bioweapon by the Doctors of Death of the US Army Medical Command at Fort Detrick or accidentally, by molecular biologists in a laboratory in the former USSR or in Eastern Europe.

A similar hypothesis linked HIV to an African strain of swine flu that had killed Cuban pigs following the importation of contaminated sounders or their deliberate contamination by the CIA. Others suggested that what Columbus brought from the Dominican Republic to Europe was HIV and not syphilis. A "EuroAmerican" origin was also "outlined" based on the similarity between HIV and other retroviruses (visnamaedi), identified in sheep in northern Europe, and its transmission through sexual contact between men and animals (see Shannon, 1991, p. 8, for all references). Another widely disseminated initial explanation proposed that the new disease had been "carried" from Canada to the United States by Gaetano Dugas, a "promiscuous" flight attendant who was known for a long time as "patient zero" (see Stein, 2007 p. A10) or from Haiti by "homosexuals on holiday" (see Camargo, 1994, p. 67, and Farmer, 2006, for references).

In the early 199os, the causal link between HIV and AIDS had generally been accepted by the international scientific community and by state and multilateral agencies (although authors like Shannon did not fail to register the "dissident" position of Peter Duesberg, which was already notorious when the work was published). According to the account presented by Shannon (1991, p. 9), three hypotheses concerning the genesis of HIV had gained prominence at the time. They focused on the geographical origin of the virus and the history of its diffusion based on the idea that "understanding the origins of HIV and the mechanisms of its transfer may eventually contribute to its control". Such assumptions, based on the dominant patterns of the epidemic, pointed to Haiti, Euro-America and central Africa as possible places of origin of HIV, as illustrated in the following figures. 
Figure 3: The theory of the Haitian origin of HIV

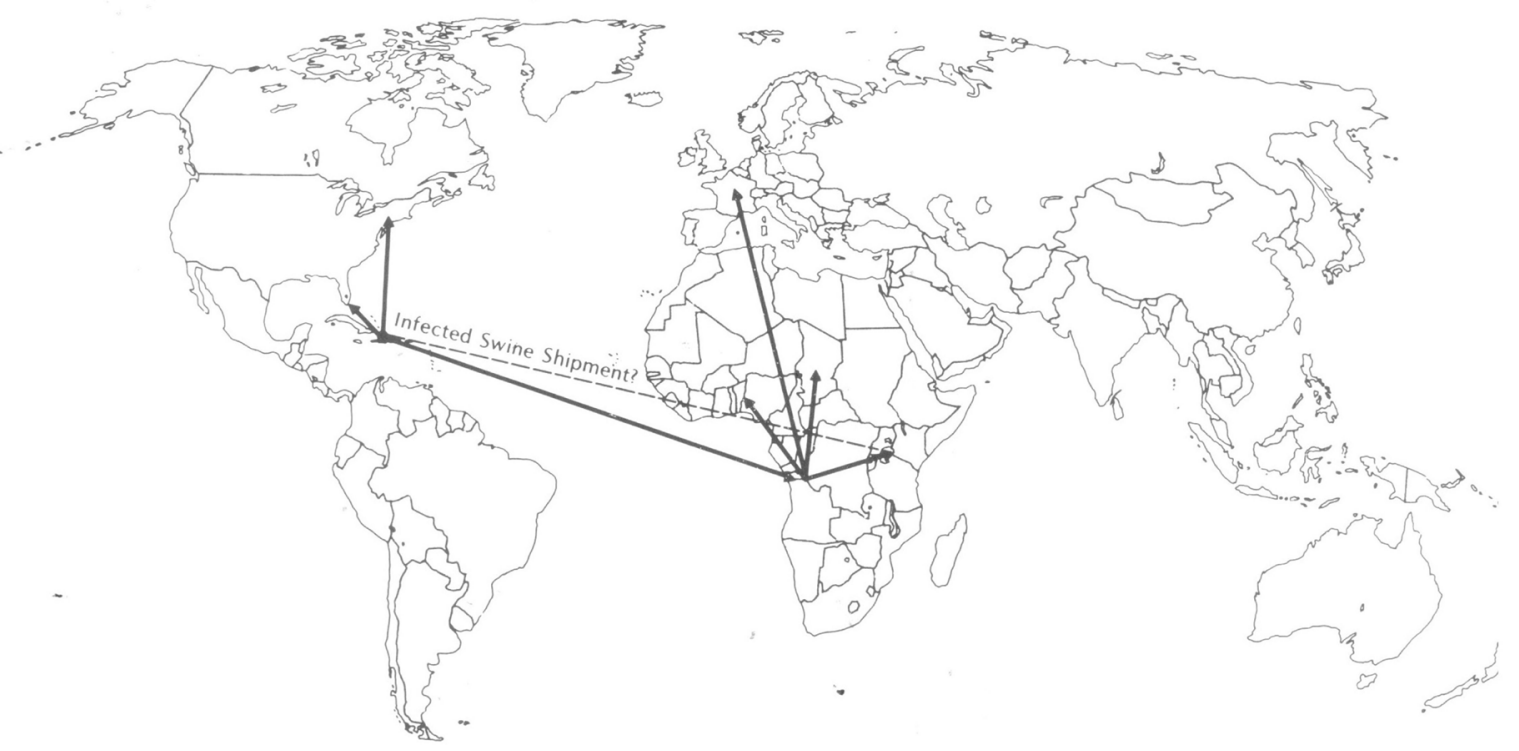

Taken from Shannon, 1991, p. 14.

Figure 4: The theory of the Euro-American origin of HIV

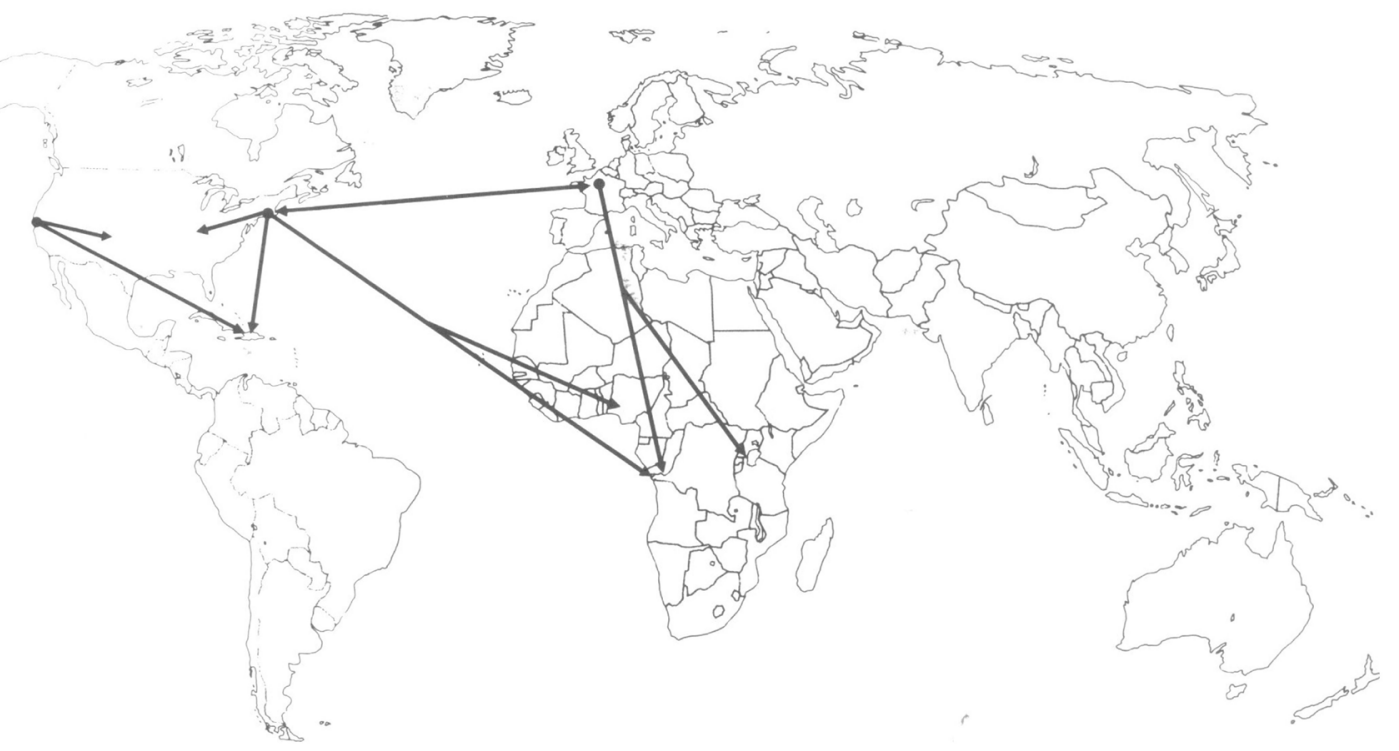

Taken from Shannon, 1991, p. 19. 
Figure 5: The theory of the African origin of HIV

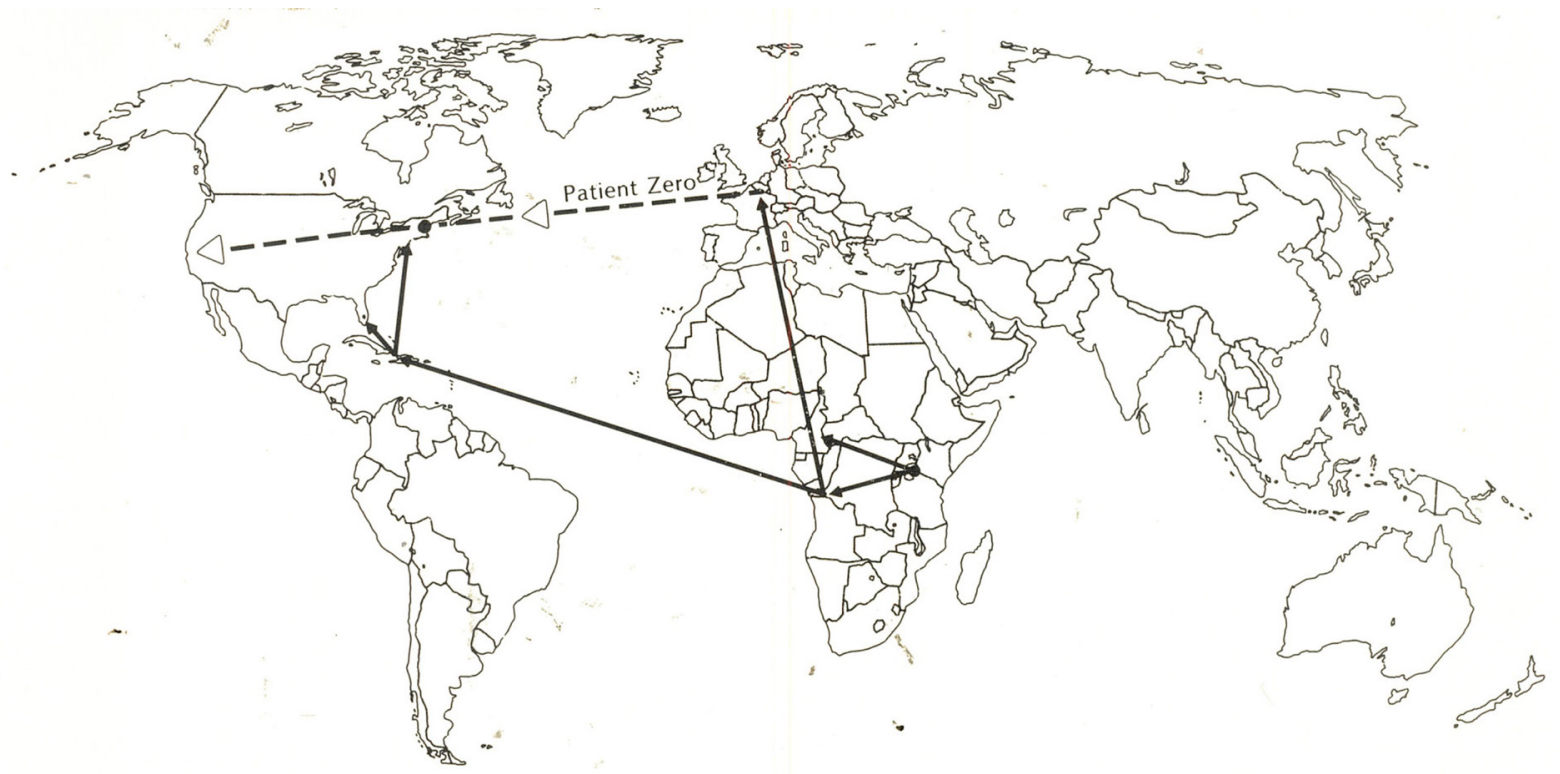

Taken from Shannon, 1991, p. 22.

Back in 1984, only three years after the first AIDS cases were reported in the United States, the suspicion was that its recently discovered aetiological agent had originated in central Africa. This suspicion arose mainly because, as Pepin observed (2011, p. 6), the first studies in Africa conducted in the Democratic Republic of Congo and Rwanda showed that AIDS was common in cities like Kinshasa and Kigali, especially among sex workers. Viewed in retrospect, the idea of central Africa as the origin of HIV, even if ultimately correct, was "naïve", as Pepin pointed out (2011, p. 6-7). The researchers assumed that, since the region had the highest prevalence among representative groups of the total adult population at the time, the virus must have originated there. Pepin highlights at least two problems with this assumption.

First, there was an "obvious bias" because at the time, there was little information on the prevalence of HIV in other parts of the continent, notably eastern and southern Africa. Belgian researchers, in particular Peter Piot, who would become the first executive director of UNAIDS, had begun research in the former colonies of their country, where they maintained networks and contacts from previous decades. The Democratic Republic of Congo and Rwanda were open to research on AIDS from the beginning, unlike, for example, Burundi and some English-speaking countries in eastern Africa, where there was a tendency to cover up the issue.

Second, again according to Pepin, there is no direct relationship between HIV prevalence and the time when an outbreak of the epidemic occurs in a particular area. Everything depends on the annual incidence, i.e. the proportion of previously seronegative people who acquire HIV during this period. The incidence among the adult population of Kinshasa, the capital of the Democratic Republic of Congo, was probably no more than $1 \%$ annually. However, in some southern African countries, the annual incidence reached levels of $5 \%$ in the 1990 (one in every 20 adults was HIV-positive).

The virus genetically closest to HIV is simian immunodeficiency virus (SIV). According to the most widely accepted explanation, HIV originally appeared in a species of chimpanzee, Pan troglodytes troglodytes, whose natural habitat is the forests of central Africa, in the territories of the countries now called the Republic of Congo, the Democratic Republic of Congo, Cameroon, Gabon, the Central African Republic and 
Equatorial Guinea ${ }^{10}$. SIV likely emerged as a recombination of various classes of viruses present in small simians that form part of the diet of P. t. troglodytes. In an attempt to trace the route of virus propagation, Brandon et al. (2006) proposed that it was initially transmitted to humans in southern Cameroon, on the border with Congo, and then continued southwards along the Sangha River, until it reached the Congo River, and finally Kinshasa.

Based on molecular clocks of the genetic variation of the virus, Pepin (2011, p. 42) affirmed that the common ancestor of HIV-1 has been identified in humans since the 1920s. At a time of extensive European colonial expansionism in Africa and broad circulation of firearms, hunting these chimpanzees with rifles, instead of arrows and native darts, became much more common. Pepin proposes (see Chapter 4) that the HIV epidemic most likely initiated as an "occupational infection", i.e. through casual handling of bushmeat and contact with the blood of hunted chimpanzees, especially among hunters and cooks. Such incidental cases of interspecies transmission must have occurred for hundreds of years, since humans and chimpanzees of the species P. t. troglodytes have coexisted in the forests of central Africa for generations.

Even though his main objective was to show how "history confirms molecular clocks", the microbiologist Pepin devotes a considerable part of his book (Chapters 5 and 6) to describing the "background" in which, in his words, "the rest of the story took place". This work refers to the sociohistorical conditions, from the 1920 s onwards, that enabled cases of SIV transmission to humans, which had long existed, and that disseminated in such a way as to give rise to the HIV epidemic. These conditions refer mainly to the history of European colonialism in central Africa and its impact on commercial circuits (including prostitution), the displacement of populations and demographic change, urbanisation, sanitary systems and disease control policies.

For example, the mining heyday of the Congo in the first half of the twentieth century caused the displacement of much of the population and an increase in prostitution. In addition, opening up roads and railways increased the movement between locations and the population in transit. Later, in 1960, following the independence of the former Belgian Congo and French Congo, the region experienced a period of political and social turmoil that led to an increase in the existing poverty, in prostitution and in the displacements, further facilitating sexual transmission of the virus. Regarding the relationship between colonialism and prevalence of HIV in Africa, Pepin warns:

Africans understandably resent and reject as arrogant, or at least Eurocentric, historical accounts of their continent which consider the European penetration as the starting point and describe this process as discovery rather than what it really was: a military conquest for the purpose of economic exploitation. [...] the events relevant to the emergence of HIV-1 occurred during the colonial occupation of central Africa, and were facilitated by the profound social and economic changes brought about by colonisation, especially around the pool on the Congo River [...] (2011, p. 59).

After it affected humans, during recent decades, HIV has desolated sub-Saharan Africa on an extraordinary scale, to the point where two thirds of the world population affected by the virus live in this region and half of the cases in the world occur in the "AIDS Belt"-so named during the initial phase of the epidemic - , a group of countries in eastern and southern Africa, in which only $11 \%$ of the global population resides. According to Goliber (2002), although the precise definition of the AIDS Belt may vary, it includes approximately 16 countries: from Djibouti and Ethiopia in the northeast, traversing the entire eastern

10 This specifically concerns HIV-1 group M, the prevailing type in the global epidemic. Other types (HIV-2 and HIV-1 groups O, N and P) are less common forms of the virus. HIV-2 originated in a different species of chimpanzee whose natural habitat is West Africa. 
continent, Ugandan, Kenya, Tanzania, Rwanda, Burundi, Mozambique, Malawi and Zambia, and ending in South Africa and the small countries located within its territory (Swaziland and Lesotho). The countries most affected by the epidemic are contiguous, are situated in the southern part of the continent, and include South Africa, Lesotho, Swaziland, Botswana, Namibia and Zimbabwe (Caldwell \& Caldwell, 2003; Goliber, 2002; Timberg, 2006). According to a global report of the epidemic, to date, sub-Saharan Africa remains the most affected region, with approximately 25 million of the nearly 35 million people living with HIV worldwide. Even though the number of new cases of HIV among adults has decreased 34\% since 2011, it is also true that $70 \%$ of new cases registered in 2012 were located in this region (UNAIDS, 2013).

Attempts to reconstruct the genetic evolution of HIV and trace the "true path" of its expansion have indicated that "the insidious pathogen used Haiti as a stepping-stone from Africa to the United States and arrived much earlier than had been thought. It then simmered silently here for more than a decade before it was detected, beginning its global spread along the way" (Stein, 2007, p. A10). Gilbert et al. (2007) proposed a geographical and chronological sequence of the emergence of the AIDS epidemic beyond sub-Saharan Africa, based on the route of HIV-1 (group M subtype B), the HIV variant most common in other regions of the world (see figure below). According to the authors, HIV-1 "moved" from Africa to Haiti in (or around) 1969 (between 1962 and 1970), developed gradually in this area for some years and from there, dispersed to other places (which is why they called their model Haiti-first). This would explain, again according to the authors, why the first HIV epidemic outside Africa was registered in the country and the high prevalence of HIV-1 among Haitians in the early 1980s. Due to its 40-year history in the country, the HIV-1 epidemic in Haiti exhibits a broad genetic diversity, more than all the subtype B variations combined in the rest of the world, as occurred with the entire group M in the epidemic in the Democratic Republic of Congo.

Figure 6: Emergence and dissemination of HIV-1 (group M subtype B) according to the study by Gilbert et al. (2007)

\section{Tracing One Branch of a Pandemic}

Scientists follow genetic markers to identify the origins of a widespread strain of the AIDS virus, HIV-1 subtype B.

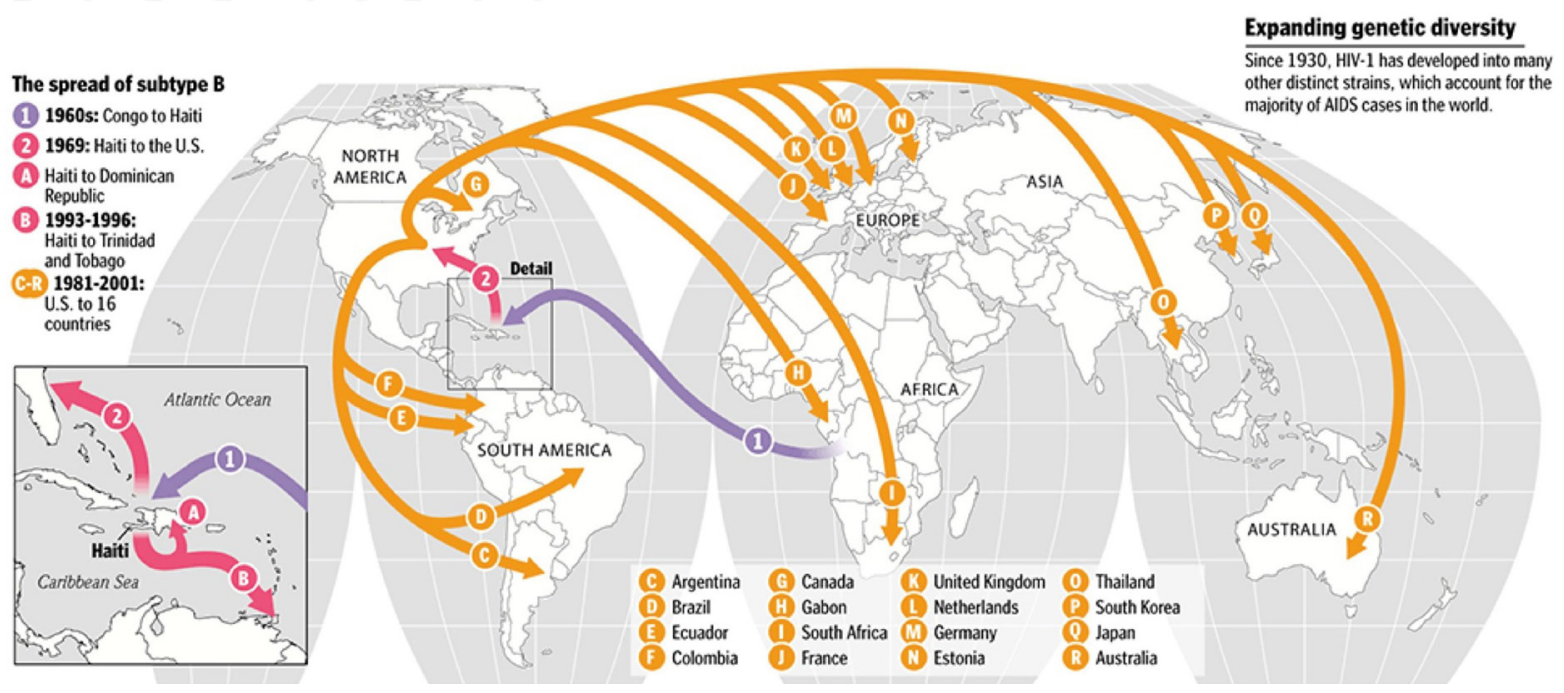

Taken from The Washington Post, $5^{\text {th }}$ of November, 2007.

There have been numerous attempts to explain the emergence of HIV in Haiti (for a critique of these explanations and an alternative hypothesis, see Farmer, 2006). For Pepin (2011), the most likely explanation has to do with the arrival of Haitian teachers and officials (francophones like the Congolese) in the Congo, who were part of UN humanitarian missions following the independence of the African country. Some of 
these Haitian teachers and officials acquired the virus through sexual intercourse with people in the Congo and took it back home with them. From Haiti, the virus continued its route to the United States. Between 1955 and 1975, for example, the US government was plunged into a fierce war against Vietnam and blood banks could not cope with the demand for plasma and other blood products for their combatants in Southeast Asia. Thus paid donation centres were established in Latin America and the Caribbean; in Haiti, where poverty was widespread, the sale of blood was extensive. According to Pepin, other routes and modes of transmission are possible (e.g. transmission of the virus in Europe by people from Africa and sex tourism in the Caribbean), but a centre called Hemo-Caribbean, owned by a leader of the Tonton Macoute, the paramilitary militia of the Duvalier dictatorship, played a special role in the exportation of plasma from Haiti. This centre sent between five and six thousand litres of blood to New York, one of the future core areas of expansion of the epidemic.

\section{Problems of definition}

In North America and Europe and in so-called developed countries, in general, HIV transmission through homosexual relations and the use of unsterilised syringes among intravenous drug users has been a recurring theme in explanations concerning the spread of the virus. In contrast, the focus of virus epidemiology in subSaharan Africa has been heterosexual relationships and similar distribution among men and women. Since 1982, many different definitions have been used for national and international epidemiological surveillance. In concrete terms, "epidemiological surveillance" means statistically registering AIDS cases based on a list of medical conditions and diseases associated with it. According to a general use, confirming a diagnosis of AIDS in Europe and the United States requires, confirming a diagnosis of AIDS in Europe and the United States requires: 1) a reactive test (positive) for HIV; 2) a $\mathrm{CD}_{4}$ (T lymphocyte) cell count below 200; and 3) the presence of one of the AIDS-defining illnesses. The diagnosis of AIDS includes a number of unrelated illnesses, ranging from several forms of mycosis and candidiasis to pulmonary tuberculosis, recurrent pneumonia or invasive cervical cancer. An HIV-negative person can also develop these diseases, but that does not mean they have AIDS; in any case, a diagnosis based on laboratory tests is required.

However, by the mid-1980s, the difficulties of using this definition in "developing" countries had been posited, especially in regions like sub-Saharan Africa, due to the lack of equipment and laboratories for sophisticated tests. In 1985, the WHO provisionally adopted the so-called Bangui Definition. This definition was based on a "clinical diagnosis", i.e. "symptoms" (complaints reported by the sick) and "signs" (changes perceived by a health professional), without requiring laboratory confirmation. However, use of this definition continued and, with major or minor modifications, was adopted permanently (Gilks, 1991). It included four main criteria (chronic asthenia, significant weight loss, chronic diarrhoea and fever) and six secondary criteria (chronic cough, persistent lymphadenopathy, herpes zoster, recurrent herpes infections, rashes and oropharyngeal candidiasis). Kaposi's sarcoma and cryptococcal meningitis were sufficient by themselves for a diagnosis of AIDS. In children, the definition of AIDS consisted of three main criteria: weight loss and slow growth; chronic diarrhoea, for a month; and chronic fever, for a month; and six secondary clinical criteria: generalised lymphadenopathy; oropharyngeal candidiasis; recurrent common infections, such as otitis and sore throat; persistent cough; generalised itching; and confirmed maternal HIV infection (Keou et al., 1992). From 1985 onwards, all of these diseases were reclassified as "opportunistic infections related to AIDS" and since then, appeals have been made for Africans to change their sexual practices through abstinence, monogamy and condom use. These same pleas were extended, generally, throughout the rest of the world after a while $\mathrm{e}^{11}$.

11 Regarding problems with the classification of clinical cases and, therefore, with the definition of AIDS, see also Camargo (1994, p. 70). 
Paradoxically, according to Marques (2005, p. 577-578), attempts gradually to adjust HIV to the model of "global epidemic" and AIDS to that of "chronic illness", with individual preventive actions and a "healthy lifestyle", appear to have barely responded to its comprehensive social dimension. According to the author, the illness belongs to the other, and as a "chronic disease", continues to highlight the chronic social inequalities, which are tolerated to the extent that it is only the other who dies. Such inequalities, however, are not restricted to economic differences between "rich" and "poor", between "First World" and "Third World", but are also framed in terms of ethnicity and nationality, given that, as a "global epidemic", it also challenges the ways borders are managed, particularly when it comes to controlling immigration and tourism, as Hyde shows (2008). For Hyde (2008, p. 204), "the notion of barbarians and barbarian diseases is revealed not only in historical accounts of northerners' conceptions of southerners' diseases but also in the everyday speech of northern tourists".

Problems arise with the differences that AIDS reinforces precisely when alterity is viewed as pathological, including from the point of view of experts, because, as Becker warns (2008, p. 22), when research aims to discover the aetiology of the disease it seeks mainly to unveil the causes of undesirable behaviour. At the height of the objectification of this alterity, the "dangerous other" and the "sickly" also becomes an enemy. In Eco's words (2012, p. 3), "enemies are different from us and observe customs that are not our own. The epitome of difference is the foreigner" (emphasis in original). Thus, it is not random that the very search for the origin of HIV, particularly at the onset of the epidemic, suffered resistance from some national governments who denied the existence of HIV or AIDS in their countries and prohibited the entry of people identified as HIV-positive into their territories (see, for example, Hyde, 2008; Pepin, 2011, p. $7)^{12}$.

Thus, we are faced with the account of a virus emerging and gradually moving across Africa that later explodes worldwide; an infectious disease resulting from promiscuous and unprotected sex and, at the heart of explanations, certain assumptions that allude to the relationships between race/ethnicity/ nationality, disease and health. It is as if certain characteristics of certain individuals and groups, owned or assigned, are the determining factor; as if, in the case of Africa or Haiti, birth or nationality per se are enough to explain the phenomenon of HIV and justify the exclusion of these people (as occurred with the Red Cross pamphlet). This despite the controversies and the arguments that speak in favour of other forms of explanation.

Paul Farmer (2006, p. xii), for example, in direct opposition to the "Haiti-first theory", has characterised the HIV epidemic in the country as a "sub-epidemic" derived directly from the epidemic in the United States, which in turn, is not related to the epidemic in Africa. According to Farmer, the technologies developed from 1992 onwards have allowed us to characterise the genetic subtypes (or strains) of HIV and corroborate the thesis that he proposed: the HIV epidemic in Haiti was caused by subtype B, the prevalent strain in the United States. Again according to Farmer (2006, p xii), "AIDS did not come to Haiti from

12 To date, according to UNAIDS, 35 countries, territories and areas officially impose some form of restriction on the entry, stay and residence of people living with HIV based on their HIV status. Five countries completely prohibit the entry or stay of HIV-positive people in their territory, regardless of the reason and duration of the trip (tourism, business, political asylum, refuge, etc.), namely, Brunei, Oman, Sudan, United Arab Emirates States and Yemen. Seventeen countries deport individuals once their HIV-positive status is discovered: Brunei, Bahrain, Malaysia, Syria, Qatar, North Korea, United Arab Emirates, Egypt, Russia, Iraq, Saudi Arabia, Jordan, Singapore, Kuwait, Oman, Yemen and Sudan. Thirteen countries, including the United States, China, Ukraine, Armenia, Namibia and Fiji, recently removed all barriers that prevented the entry of HIV-positive people. In 2010, President Barack Obama withdrew these barriers to the United States, thus allowing the country to host the International AIDS Conference again, in 2012, after 2o years. For a complete list of these restrictions by country, see http://www.unaids.org/en/resources/infographics/20120514_travel. Accessed on: $4^{\text {th }}$ of Sept., 2015. 
Africa, where other clades are prevalent; it came south with North American tourists", notwithstanding, the "myth" that AIDS arrived in the United States from Haiti persists and reinforces the North American folk model that has historically made Haiti an "exotic", "strange", "hopelessly diseased" country, in short, "a little Africa”.

In the figure below, together with the text of the Durban Declaration, which is probably well intentioned when it states that "HIV recognizes no social, political or geographic boundaries", note the inclusion of a photograph with black children (African?) and a global map highlighting in red the concentration of HIV/AIDS in African countries (mostly in the previously mentioned "AIDS Belt").

Figure 7: Durban Declaration

commentary
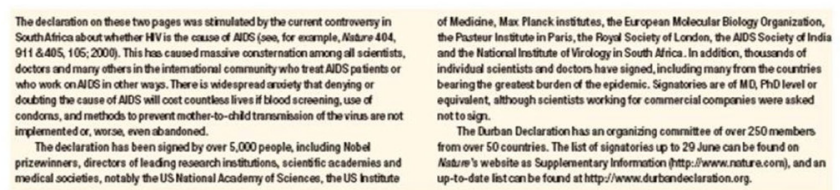

The Durban Declaration

HIV causes AIDS. Curbing the spread of this virus must remain the first step towards eliminating this devastating disease.
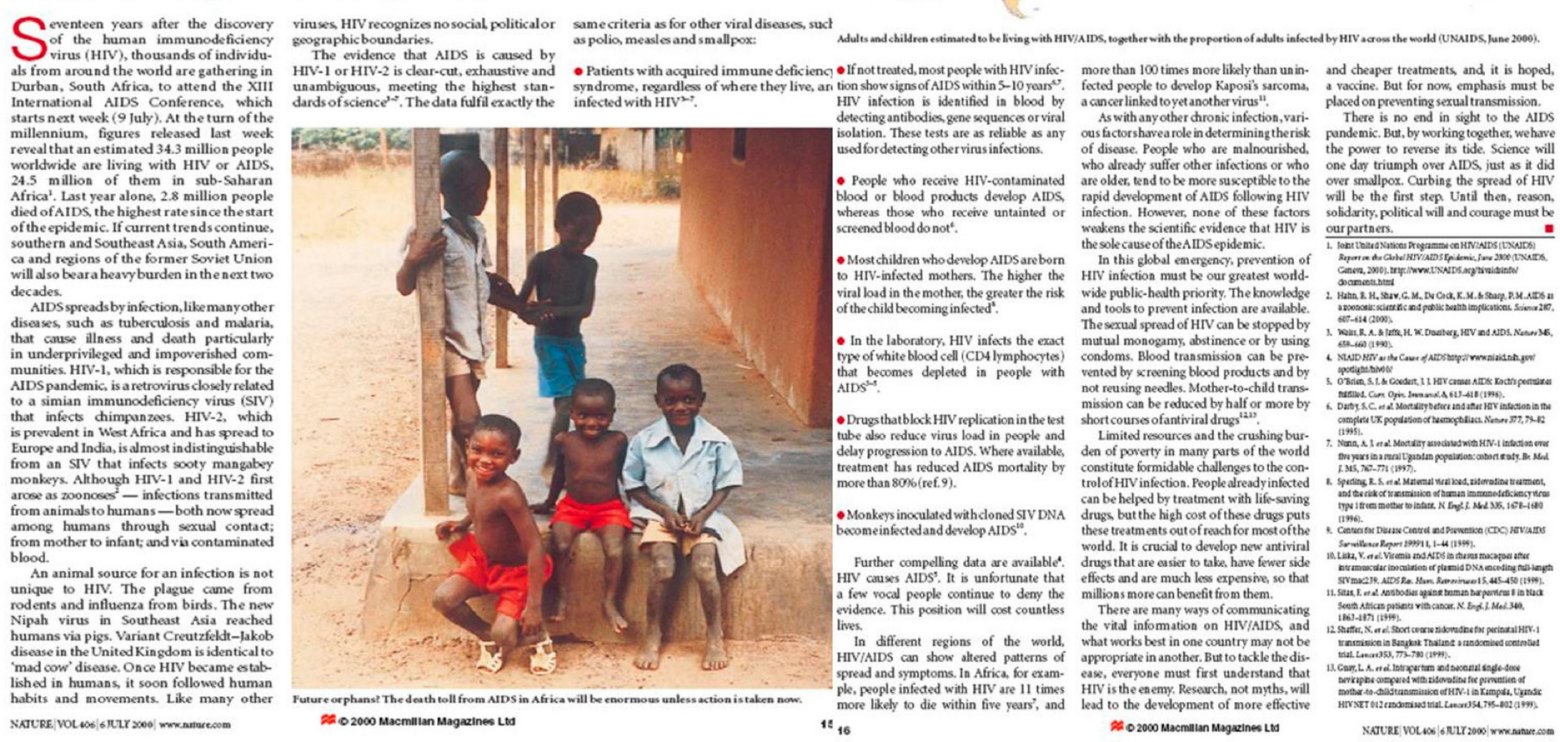

Published by the journal Nature on the $6^{\text {th }}$ of July, 2000

Just like the initial assumptions about the genesis and distribution of diseases like tuberculosis and syphilis, in the case of AIDS, the existence of particular characteristics of Africa and Africans has been invoked to explain their high vulnerability to the disease. Historically situating the stigmatisation regarding AIDS, Stephenson (1991, p. 97) brought to the fore the controversy over the origin of the syphilis epidemic that afflicted Europe in the fifteenth and sixteenth centuries: 
... even today, in paleopathology, the debate between the proponents of the New World as the place of origin of the epidemic and those of the Old World, is simply a new echo of this attitude. We again speak as if the disease was caused by classes of people (Europeans or Native Americans) and not by a microorganism. The English of course nicknamed syphilis "the French pox" and the French "the English pox"; for Christians, it was a "plague of Egypt" and for the Turks, who perhaps remembered the voracious appetite of the Crusaders for their wives and children, it was the "disease of Christians". ${ }^{13}$

Paraphrasing Ferguson and Mbembe (see Ferguson, 2006, p. 5-6 for all quotes), notions like "AIDS Belt", "Haitian stepping-stone" and "endemic areas" are less an empirical phenomenon, a geographical accident, than entities through which a world is structured. It is an imposed fact, imperative, of categories within and according to which people live. In the case of Africa, they acquire a force such that, as Mbembe has provocatively stated, "there is no description of Africa that does not involve destructive and mendacious functions", sometimes even when it is done by Africans themselves. In his introduction to Global Shadows (2006), for example, Ferguson cites "the case of two impoverished Guinean boys who write a letter seeking help from 'members and officials of Europe' on behalf of 'we the children and the youth of Africa' and who use the word 'Africa' or 'African' no fewer than eleven times in their brief, one-page letter'. He then speaks of "a group of highly educated young Zambian nationalists [who] move from an optimistic discussion of a new national Zambian culture to an anguished debate on whether 'Africans' suffer from generic cultural inferiority". Situations like these, Ferguson discloses, "serve to remind us that it is not only scholars who give credence to a constructed African "geo-body" [...] dubiously artificial and powerfully real". The summation ends with a quote from Mbembe: "when it comes to the category of 'Africa', the 'oscillation between the real and the imaginary, the imaginary realized and the real imagined, does not take place solely in writing. This interweaving also takes place in life"'.

In the clash of divergent explanations of its origin, spokespersons and experts have participated in the production of such notions as the "AIDS Belt" or "Haitian stepping-stone" and, more generally, in the stigmatisation of HIV and AIDS. I maintain that it is possible to link the analysis of these divergences to a reflection on social relationships, particularly in reference to configuration processes of alterity, identification and belonging, either within the sphere of producing an individual or collective self (e.g. "HIV-negative" versus "HIV-positive", AIDS “orthodox" versus AIDS "denialists", as in the case of the South African debate), or in the sphere of the construction of a geopolitical category like the nation-state. Therefore, as a working hypothesis, I propose that the aetiology, natural history and epidemiology of AIDS is also related to native theories of causality, in the wake of what could be called an enlightened common sense of specialists and spokespeople of the disease. Here, as in the topics of denunciation analysed by Boltanski (1984; 1993, p. 101), the enunciates of the distinct postures adopted are often inscribed in a structure of controversy, which is specifically expressed in the opposition-as in the South African debate - that the participants establish between "orthodoxy" and "dissidence", "denialism" or "alternative theories" or, more broadly, between "AIDS science" and "pseudoscience", in whose production scientists play a privileged, though not exclusive, role.

\footnotetext{
13 Original in French: « ...même aujourd'hui, en paléopathologie, le débat qui oppose les partisans du Nouveau Monde comme lieu d'origine de l'épidémie à ceux du Vieux Monde est simplement un nouvel écho de cette attitude. Nous nous exprimons encore comme si la maladie était causée par des classes de gens (Européens ou autochtones d'Amérique) et non par un micro-organisme. Les Anglais surnommaient évidemment la syphilis «la vérole française» et les Français «la vérole anglaise»; pour les chrétiens, c'était une «plaie d’Égypte» et pour les Turcs, qui se rappelaient peut-être l'appétit vorace des Croisés pour leurs femmes et leurs fils, c'était la «maladie des chrétiens». " Stephenson (1991, p. 97)
} 


\section{The AIDS debate in South Africa}

According to UNAIDS, South Africa is in the midst of an HIV epidemic, with more than five million HIV-positive individuals ${ }^{14}$. In 2000, with almost 80,000 HIV-positive newborns per year in the country, the use of an antiretroviral called nevirapine offered the possibility of reducing virus transmission to 30,000 to 40,000 children per year. The manufacturer offered the product free to the South African government for five years. But the government refused, announcing the introduction of a comprehensive program to prevent HIV transmission from mother to child. The program included two pilot projects in each of the nine South African provinces, where individuals would be offered nevirapine, counselling and infant formulas as an alternative to breast milk, for two years; upon completion of this period, an assessment would be made. In addition to evaluating the efficacy and safety of nevirapine, the reason given by the government for this limited access to medicine was the need "to determine whether or not the exercise would be feasible, taking into account all the operational issues. Should the pilot sites be successful, the next step would be phased implementation; should this not be possible the exercise would be terminated" (Heywood, 2003, p. 286).

In April of the same year, the president of South Africa, Thabo Mbeki, sent a letter to world leaders expressing his doubts that HIV was the sole cause of AIDS. In the letter, he emphasised the "socioeconomic causes" of the disease and invited scientists who shared this point of view to form an international panel, together with scientists from the "orthodox" current-those who claim that HIV is the cause of AIDS-, that would advise his government in response to the epidemic in South Africa. In the text, President Mbeki remembered the order given the previous year to his Health Minister, Manto Shabalala-Msimang, "to look into various controversies taking place among scientists on HIV/AIDS", in order to "put together an international panel of scientists to discuss all these issues in as transparent a setting as possible" ${ }^{15}$.

In July of the same year, during the opening speech at the XIII International AIDS Conference in Durban, Mbeki avoided any reference to HIV and, instead, focused again on poverty as a powerful AIDS cofactor. In his speech, the president also defended certain groups that disputed HIV as the cause of AIDS. In response, more than five thousand scientists signed the so-called Durban Declaration (2000), which asserted categorically that HIV is the cause of AIDS and to affirm the contrary would cause many deaths. From that point on, the president was subjected to heavy criticism and his government was accused of offering an inadequate response to the epidemic.

After numerous attempts to convince the Minister of Health of the urgency of expanding the programme to prevent HIV transmission from mother to child, the Treatment Action Campaign (TAC), which would become the most prestigious AIDS NGO in the country, challenged the constitutionality of the measures taken by the government, claimed violation of the right to health care of the mothers who did not have access to the pilot projects and filed a lawsuit in the Pretoria High Court requiring the distribution of the drug throughout the country. In December 2001, Judge Chris Botha ruled in favour of the TAC, ordering the government to: 1) provide nevirapine to HIV-positive mothers who gave birth in public health institutions; 2) submit to the court a plan to expand provision of the medication in the public health sector throughout the country. The government appealed this decision in the Constitutional Court and Judge Botha granted an injunction to the TAC while the appeal was under review. The Court agreed to decide in this case, acknowledging that the dispute involved a matter of a constitutional nature, but rejected

\footnotetext{
14 Available at: http://www.unaids.org/en/regionscountries/countries/southafrica/. Acesso em: 04 set. 2015. Accessed on: 4th of Sept., 2015.

15 South African President Thabo Mbeki's letter to world leaders on AIDS in Africa. Available at: http://www.pbs.org/wgbh/pages/frontline/aids/docs/ mbeki.html. Accessed on: $5^{\text {th }}$ of Sept., 2012.
} 
the government's appeal. Since the government did not present any convincing argument regarding the reasons why it could not comply with the Pretoria High Court order, the Constitutional Court ordered the expansion of the provision of nevirapine, the provision of HIV counsellors and that reasonable steps be taken to increase the number of counselling and testing locations throughout the public health sector.

Litigation to prevent HIV transmission from mother to child was the inaugural moment of what became known as the "AIDS debate" in South Africa. In the debate, which lasted over a decade, advocates of the scientific consensus that HIV causes AIDS and that antiretroviral drugs are the best treatment available, clashed with those who defended the explanations of "dissidents" and "denialists" - notably those who assert socioeconomic factors or recreational drug intoxication or even the use of antiretroviral drugs as causes, together with certain lifestyles, for example, that of homosexuals.

According to Heywood (2003: 281-282), while Nkosazana Dlamini-Zuma was Minister of Health, during the presidency of Nelson Mandela (1994 to 1999), it seems cooperation existed between the TAC and the South African Department of Health. At the time, the TAC had avoided pressuring the government to provide antiretroviral drugs, given that the costs made them inaccessible. When the South African Parliament reformed the Medicines Act, in 1997, to allow local production of generic versions, 39 pharmaceutical companies filed a lawsuit against the government for infringing patent law. The TAC joined the then government and helped to exert pressure that led the pharmaceutical companies to drop the lawsuit. The organisation also proved successful in lobbying and publically campaigning to reduce drug prices.

Disagreements between the TAC and the government only began to appear at the end of 1999. According to Heywood (2003), when the TAC initiated the procedures in 2001, under President Mbeki's rule and with Manto Shabalala-Msimang as Minister of Health, none of the government's declarations alluded to the arguments of "dissidents" or "denialists" on antiretroviral drugs, nor was HIV questioned as the cause of AIDS, in order to justify its failure to implement a prenatal program to prevent HIV transmission. However, though more or less hidden, President Mbeki's relationship with AIDS “denialists" seemed to be the main reason for government delays and interference, as several authors have repeatedly pointed out (Berger \& Kapczynski 2009; Cameron 2005a; Fassin 2007; Geffen 2010; Gevisser 2009; Herwitz 2006; Heywood 2004; Myburgh 2007; Nattrass 2007; Sitze 2004).

Since Mbeki, the discrepancies between AIDS "orthodox" and AIDS "dissidents" or "denialists" in South Africa came to be described as a "struggle between activists, scientists and health workers, on the one hand, and a strange alliance of dissidents, quacks and political leaders, on the other" (Geffen 2010: cover). In this vein, the debate has been the subject of a growing number of analyses, which favours the political economy of the epidemic in the country and the humanitarian drama caused by the Mbeki government's support of AIDS "denialists". In an environment where the language of accusation and denunciation has reigned, appeals to the "scientific governance of medicine", "evidence-based medicine", taking a stand and "combating denialism" made by advocates of "AIDS science" raise issues regarding the modes of production of sensitivities and moral regulation that enhance the understanding of AIDS as a social problem.

Since its emergence, AIDS has been the terrain of multiple controversies in the sphere of science, but it is not this that seems to have been definitively brought into play in the South African case. For activists and scientists, there simply was no debate about AIDS, rather there was "scientific consensus". From the perspective of the TAC, access to a prenatal program to prevent HIV transmission was, above all, an issue of public health policy. According to Heywood (2003, p. 299), the situation could have been treated like similar issues, for the purposes of which jurisprudence already existed. However, the influence of "dissidents" and "denialists" would have made the Mbeki government insist on stating that there was a scientific debate surrounding the causes of AIDS and the safety and efficacy of antiretroviral treatments. That is to say, for 
the "orthodoxs" there was no dissent, at least not in the terms posited by "dissidents" and "denialists", but clear agreement regarding the cause, transmission, prognosis and treatment of the disease. Paradoxically, this position also echoed the opinion of "dissidents" like Roberto Giraldo, for whom the nature of the debate was not "technical" but "political"16. Even for Mbeki, there seems to have been a shift in the initial interest in the discussion on the scientific aspects of AIDS to that of an eminently political issue:

Over the course of two years, what had begun as a quest for scientific truth, arising out of a genuine concern for the welfare of his people, had morphed, via a polemic against orthodoxy and a call to open inquiry, into an impassioned cry for self-determination and for the rights of the South, of Black people, to make their own decisions and to resist a new wave of slavery-'we are not available to be bought, whatever the price'-from the North. (Gevisser, 2009, p. 287).

Judging by the judicial decisions that systematically favoured the demands of the TAC, starting with the nevirapine dispute in 2002, the Mbeki government, and with it the "dissidents" and "denialists", failed at least twice to promote the debate on AIDS in South Africa. First, from the viewpoint of the law, the government failed to convince the courts of the reasonableness of its AIDS policy, or adjust to the principles governing litigation in these cases, particularly with regard to the strength of their "evidence" in the light of scientific knowledge, which the judges of the court were provided. They also failed from the point of view of scientific truth, because without peer-reviewed publications, with their titles and academic credentials contested, with their personalities suspected of abnormality and, above all, without "evidence" that conformed to normal science, the position of AIDS "dissidents" has been marginal or, in Boltanski and Thévenot's terms (1991), "insuffisante". In contrast to the successful "judicial activism" of the TAC and its partners (Heywood, 2003; 2004; Robins, 2004), the government failed twice when dealing with the truths of science and the principles of law. I propose that the common element in this situation, whether in opposition or in overlapping domains is, in any case, the normative basis of science and law. The sui generis element raised by the South African case is that due to Mbeki's unusual involvement with "dissidents" and "denialists", this failure also led to the crisis in AIDS public policy in South Africa, exacerbating the social contradictions historically linked to the epidemic.

\section{Explaining Mbeki}

Almost two decades after the onset of the epidemic, Mann and Tarantola (1998) had already verified how the global response to AIDS illustrates the fact that the manner in which a problem is defined determines what we believe can be done and what in fact is done to face it. In the late 199os, the authors proposed four phases to characterise the global response to HIV/AIDS: from being considered a "danger" that it was essential to be aware of, it became an individual behavioural problem; then, a question of behaviour, but "societally contextualised"; and finally, it was defined as an issue fundamentally linked to human rights. For these authors, "the HIV/AIDS response recapitulates the history of public health, and how it has faced, and the need to address, the challenges of human behavior".

Bastos (2002, p. 36), in turn, points out that the dominant perspective of AIDS defined the epidemic based on a number of relevant variables for "developed countries" and on other variables for "developing

16 Taking advantage of his move from the US to Brazil, between 2010 and 2012, I conducted seven interviews with Roberto Giraldo, one of the more visible AIDS “dissidents" engaged in the South African controversy. Giraldo would become a key informant, because, despite many attempts and contacts made by me in South Africa, he was the only "dissident" willing to talk and to whom I had direct access. 
countries". Regarding the former, the existence of "risk" in certain groups was emphasised as a function of individual behaviours, such as homosexuality and injecting drug use. Regarding the latter, the explanation of the disease included social variables, such as poverty, deprivation, labour migration and explosive urbanisation. However, again according to Bastos, data from the "developing world" were not taken into account in the theoretical and methodological formulations of AIDS epidemiology on a global scale. Thus, epidemiological variations in Africa "were 'domesticated' by the definition of a secondary 'African' pattern, idiosyncratic and primarily heterosexual" (see also Shannon, 1991). Thus, two representations of the epidemic were drawn and polarisation persisted. According to Bastos (2002, p 87-88.):

For years African AIDS was reified as heterosexual, just as American AIDS had been reified as homosexual, notwithstanding their internal diversities. That the American "homosexual" characterisation of AIDS constructed the African "heterosexual" characterisation, providing a model of dual choice for the rest of the world, is a clear example of how epidemiology resorts to local categories, not always of universal use, and how the global characterisation process of the epidemic was asymmetrical, accepting as universal a particular local knowledge, that of the United States in the 1980s [...] AIDS may not have begun in America, but it was there that it had its "cognitive birth", a fact that simultaneously saved time and lives and forever marked our understanding of the epidemic [...] The definition of the epidemic in "retrospect", from north to south, globalised and apparently unified the world around a common problem: everyone shared the new epidemic. However, this unification was only partial. Despite being one, this epidemic was defined as if it were two: it was a two-headed AIDS, with a primary pattern and a secondary pattern, distinct and non-overlapping. Assuming individual behaviour as a relevant variable to define the epidemiology and epidemiological patterns, a dual model was perpetuated that merely reproduced the opposition between developed and developing nations, between first and third worlds. The reference for defining the epidemic pattern of AIDS in any country [...] has become an "American" epidemic or an "African" epidemic, thereby duplicating the opposition between development and underdevelopment.

Bastos' observation on how the HIV epidemic has been intellectually domesticated by scientists in North America and Europe is fitting, because it also indicates a kind of historical approach that does not appeal a priori to external conditions, such as the history of Africa, colonialism or apartheid (in South Africa), but to the history of the epidemic on its own terms, to use the author's expression. Such an approach contributes to a characterisation of the intellectual field of AIDS in which the description of the "thought collectives" or "thought-styles" that have predominated in the same acquire a central position (Fleck, 1979). This description does not neglect the political circumstances of production in this field, but reclaims them in the light of themes that include the forms of historicisation of an intellectual field, and for the purposes of the South African debate, of litigations, crisis situations, "social dramas", "critical events", etc.

While analysing the notion of homo sacer introduced by Giorgio Agamben, Das and Poole (2004, p. 11-12) drew attention to how in states of exception, notably war, the fundamental issue is not only that the quality of membership of the political community is denied, but that "individuals are reconstituted through special laws as populations on whom new forms of regulation may be exercised". For example, the Jews in concentration camps under the Nazi regime, Japanese descendants in the United States during the "internments" of World War II, "terrorists" in national and international security legislations after September $11^{\text {th }}, 2001$, and, I would argue, "risk groups" in connection with the outbreak of the HIV epidemic.

Moreover, while revisiting Foucauldian notions of biopower, the biopolitics of bodies and the biopolitical state, Das and Poole (2004, p. 10:27) point out that in the anthropological study of how power spreads its tentacles into the branches of social life, one of the privileged places of this process has been the 
growing role of medicine in defining normality. The continuous production of pathologies is an important technique of power (of the sovereignty of the State) and of disciplinary power. They also observed, quoting Peter Baldwin, how the particular control strategies developed by states in Europe in the late nineteenth century and early twentieth century were closely linked to the management of contagion. Concerns about regulating the health of populations immediately leads to the relationships between metropolitan centres and colonies, wherein the control of epidemics was a necessary condition to overcome the barriers that the European exploitation of colonised territories encountered. Thus, concerns about the health of the colonies and disease control techniques have become part of the repertoire of state actions through, for example, vaccination campaigns, legislation and the administration of access to health services.

Following the diffusion of Foucault's work, and other authors in his wake, reflections like these became part of our contemporary understanding of governmentality and power in the production of academic disciplinary knowledges, to the point where they can be seen as part of what I named above as an enlightened common sense, a sort of folk knowledge, of social scientists and analysts. However, they also represent a form of reasoning often criticised by some AIDS specialists that I came across during my fieldwork in South Africa ${ }^{17}$, since, in their view, such reflections do nothing more than rationalise the "denialist" discourse of Thabo Mbeki.

On the other hand, authors like Myburgh (2007, p. 296-297) explain Mbeki's aversion to "Western science of HIV/AIDS" and his adoption of the "denialist paradigm" on the basis that it was seen by the then president as simply an expression of a "repulsive and terrifying stereotype of the African barbarian". The disease had originated in Africa, was transmitted mainly through heterosexual relations of black Africans and had grown unabated and more extensively in Africa than in the West (see also Mbali, 2004; Cloete, 2007). As reported by Myburgh, Mbeki, complained in a letter to Tony Leon, then leader of the opposition to the African National Congress (ANC) ${ }_{1}^{18}$ about how "the hysterical estimates of the incidence of HIV in our country and sub-Saharan Africa made by some international organisations, coupled with the earlier wild and insulting claims about the African and Haitian origins of HIV, powerfully reinforce these dangerous and firmly entrenched prejudices" (emphasis in original). In contrast, according to Myburgh, the "dissident' viewpoint" had an "obvious attraction". In the words of the author:

It offered an escape from the sense of racial humiliation by questioning whether the disease was sexually transmitted. The idea that immune deficiency was caused mainly by poverty fitted into the old anticolonial paradigm of the liberation movement, since poverty was a 'legacy of apartheid and colonialism'. AIDS 'dissidence' allowed the ANC leadership to evade its political responsibility for the initial failure to counter the spread of the epidemic, as well as moral absolution for the blocking of antiretroviral treatment when this first became available.

In Herwitz's description (2006, p 49), the relationship between the thinking of Mbeki and his supporters and the reflections of the social sciences in the configuration of what the author calls a politique de l'indigénéité about AIDS is stated openly:

\footnotetext{
17 I stayed in South Africa as a visiting student, assigned to the AIDS and Society Research Unit at the University of Cape Town, from December 2010 to December 2011, returning for two weeks in September 2012. In 2010, while still in Brazil, I accompanied the activities of a group of people living with HIV in Rio de Janeiro who defended "alternative" approaches of AIDS and I conducted a series of interviews in São Paulo with Roberto Giraldo, one of the more visible AIDS "dissidents". My work lasted from 2012 to 2013, through dialogue with interlocutors in South Africa and daily follow-up information and discussion lists in the country.

18 The freedom movement that, having officially ended apartheid, rules in South Africa today.
} 
... they were generally influenced by Marxist rhetoric and the postcolonial outcome of the humanities and social sciences and unversed in the language of real life. Mbeki has adopted a posture of orator, intellectual, he is positioned as the spokesperson of a large slice of history in which he occupied the top, demiurgically. That it is he who became president at a time when South African health and social realities should have taken precedence over any high-flying discourses has exacerbated the turmoil. Finally, that Mbeki, in the wee hours of the night, surfing the web, could trust the pale light of animated websites by dissidents who question the consensus of biomedical sciences on AIDS, has had disastrous consequences.19

For Myburgh (2007, p. 215), Mbeki's desire for equality manifested itself in a unique way in the idea of an "African Renaissance", which became the hallmark of his foreign policy, and in the search for "African solutions" to the problems of Africa, it had one of its corollaries. Although presented as innovative and visionary, it was, of itself, an old idea, since "African nationalism has tended to include within itself an image of rebirth" (Mazrui apud Myburgh, 2007, p. 217). Mbeki's arguments, however, had become "trapped within the 'eschatological fantasy' of African nationalism", according to the author. Again according to Myburgh, Mbeki's remarks showed, "concern, obsession even, with the Western perceptions of Africa", especially with the "crude and archaic European myths of African inferiority". In these comments, affirms Myburgh, a sense of democracy is valued not for itself, but as a means of counterbalancing Western perceptions of a supposed African incapacity. In words quoted by Myburgh, Mbeki believed "we must bring to an end the practices as a result of which many throughout the world have the view that as Africans, we are incapable of establishing and maintaining systems of good governance" (emphasis in original). Thus, Mbeki's concern with the widespread poverty in Africa seemed to proceed, not so much from a sense of "compassion", but from feeling "shameful". For Myburgh, the AIDS controversy brought about by Mbeki in South Africa was emblematic of the reaction of the then President when confronted with an "Afropessimist" view (2007, p. 218-219).

In his comments in the biography Thabo Mbeki: The Dream Deferred (Gevisser, 2009), McGreal (2007) ${ }^{20}$ also suggests that the then President's views on AIDS were shaped by an "obsession" with race, the legacy of colonialism and "sexual shame". Gevisser (2009, p. 341), in turn, observed in the book:

There are [...] many reasons why Thabo Mbeki decided to question the scientific orthodoxies of this epidemic, but at the root of it was his conviction that AIDS was being used as yet another weapon in the arsenal of spreading the virus because they could not control their sexuality. By questioning the etiology of AIDS in this way he confused the science of AIDS with the politics of self-determination. The result was a mixed message from government that undoubtedly compromised its own safer-sex programing, that promoted unproved holistic and alternative treatments at the expense of antiretroviral treatments, and, most catastrophically, that delayed the rollout of a drug program.

19 Original in French: « ... ils étaient en général influencés par la rhétorique marxiste et postcoloniale issue des sciences humaines et sociales et peu versés dans le langage de la vraie vie. Mbeki a adopté une posture d'orateur, d'intellectuel, il s'est placé comme le porteparole d'un vaste pan d'histoire dont il occupait le sommet, d'une façon démiurgique. Que ce soit lui qui soit devenu Président à un moment où les réalités sanitaires et sociales sud-africaines auraient dû prendre le pas sur tout discours de haute volée a encore aggravé la tourmente. Enfin, que Mbeki, aux petites heures de la nuit, ait navigué sur la Toile, qu’il ait pu faire confiance à la pâle lumière de sites animés par des dissidents qui remittent en cause le consensus des sciences biomédicales sur le sida, a eu des conséquences désastreuses. » Herwitz (2006, p 49)

20 McGreal's comments were made for the South African edition of Gevisser's book, published in 2007. The quotes from the same book used here corresponds to the updated international edition, published in 2009. 
However, for Schneider and Fassin (2002), Mbeki's views on AIDS articulated to other broader issues of African politics and his suspicion of science and orthodoxy seemed to be a phenomenon restricted to himself, his former Minister of Health and his aides. In South Africa, many people suspect that it is black Africans who carry most of the weight of AIDS and that the medications to treat it are expensive and sold mainly by Western pharmaceutical companies. The history of malicious and manipulative health policies brokered by colonial rule and apartheid, seem permanently to encourage the opinion that the scientific discourse on AIDS may be an instrument of European and American policy or part of their cultural and economic agendas.

In contrast to this position, authors like Cameron (2005b, p. 97) refer to the stigmatisation and stereotyping of African sexuality as a fact that serves as an argument to those who fear the "conventional approach" concerning the existence of patterns of the HIV epidemic. This is, according to him, a distinctive feature of the "African form of AIDS denialism", which sees in this the consolidation of Western prejudices about Africa. Cameron associates these positions with a "belief in conspiracy", especially when the "conspiracy is racially inspired". Thus, the racialisation of AIDS in Africa is subsumed in the category "conspiracy" and, in this way, is seen with suspicion and disqualified because it is cloaked with the mantle of irrationality (see also Geffen, 2010; Kalichman, 2009; Nattrass, 2012). However, despite Cameron's statement to the effect that "it is wrong to moralise scientific explanation" (p. 99), what the AIDS debate has evinced all the time is precisely the need to consider the moral foundations of science and its moralising effect. This seems even more pertinent when dealing with a deeply moral phenomenon like the HIV epidemic and with a field like "AIDS science".

\section{AIDS and anthropology}

Several of my interlocutors in South Africa coincided in saying that one of the adverse effects of Thabo Mbeki's position on AIDS is that it had provoked, among his critics, particularly in the academic world and among social activists in the country, a refractory attitude toward any position that was not viewed by them as "pro-science", that is, clearly aligned with the biomedical model of the epidemic. The refusal of Mbeki's government and his allies to provide antiretroviral drugs within the public health system in the name of an "African solution" for AIDS ended up stifling the possibilities of recognising "traditional" healing systems. According to these interlocutors, this explained the current "medicalisation" of AIDS in the country, which includes the "uncritical" use of antiretroviral drugs as one of its most recent manifestations, now also used as a resource to prevent virus transmission - the so-called pre-exposure therapy. The extended use of these drugs, again according to my interlocutors, ends contradictions like the favouring of higher profits for the pharmaceutical industry, as well as the possible relaxation in sexual practices and the consequent increase in new infections due to the sense of security afforded by the existence of a preventive treatment.

Another consequence of Mbeki's position was a significant reduction in the space for contributions from the social sciences, as affirmed by Fassin (2007), Green (2012) and Robins (2011). This situation is, at the very least, paradoxical, because as one of my interlocutors, a nurse and teacher in a major South African hospital, pointed out, Mbeki did not say anything new with regard to AIDS, at least "nothing that health workers or social scientists did not know or had not pointed out well before him". This observation, moreover, could explain why, for the most hardened critics of any position that does not strictly conform to "AIDS science", the discourses of certain social scientists and others engaged in discussions concerning the epidemic sound so much like Mbeki. 
The explosive nature of the denouncements of stigmatisation and discrimination posed by Thabo Mbeki certainly did not reside in their scientific consistency, but in their political reach. By adhering to the so-called "denialism" and insisting on these denunciations, Mbeki not only caused the failure of official AIDS policy in South Africa-especially regarding the vital issue of access to antiretroviral treatments-, but also evinced the difficulty of the international scientific community in incorporating into the hegemonic model of the epidemic, critical issues of particular interest to "Africa" and "Africans". In other words, Mbeki's position highlighted the historical difficulty of the scientific community to incorporate specificities, concerns and contributions of the geographical and political Third World into theoretical and methodological formulations of AIDS epidemiology (Bastos, 2002, p. 36). According to Fassin and Schneider (2003, p. 495): "Had a coherent social epidemiology of HIV been more prominent in the scientific arena, rather than the dominant biomedical and behavioural approach, Mbeki might have found interesting alternatives to the explanations of the epidemic given on the dissidents' websites".

As Schoepf also observed (2001, p. 340), the focus of epidemiologists on individual behaviour, their claims of total objectivity, devoid of values, and their trust in surveys as the sole method of science have been their entire responsibility. This has led to an excessive belief in the ability of individuals to make rational choices about their sexual behaviour based on information; it has given new impetus to the idea that there are people in "high risk" and "low risk" groups (or, in more recent parlance, more or less "vulnerable" or more or less "exposed" groups), neglecting the variations in conduct within these groups and reinforcing the stigma and prejudice to which they are subject. Moreover, assumptions like these are often unaware of the specific meaning that notions like "sex" acquire in different cultural contexts. Finally, research based solely on surveys encounters the limitation imposed by the fact that, as a rule, what people say they do differs from what they actually do. To some extent, surveys may shed light on behaviours and attitudes, but they can hardly tease out meanings. This seems to be work that is more appropriate for ethnography.

Schoepf (2001, p. 340) is resolute in her assertions regarding the prevailing epidemiological perspective: "[t] he choice of epistemology was political rather than disciplinary". As she also observed, there are critical traditions within epidemiology itself and within public health that have used more social approaches, beginning with Virchow, who in 1848, had already recognised that in order to preserve health, medicine should intervene in social affairs and politics. Some health planners, including doctors and epidemiologists, offered other views of AIDS, often working in close collaboration with social scientists, which included contributions to the social production of the epidemic in Africa. For Schoepf, "[s]truggles over meaning were international and interdisciplinary, as African and western researchers contested the narrow paradigm and its implications. They were ignored" (see also Ramin, 2007, p. 127). Reflecting on the South African case, Fassin (2007, p. 17) states bluntly: "if there had been more active opposition to the resolutely behaviorist and strictly medical approaches to the disease so dominant in international public health circles during the first two decades of AIDS, this might have opened a space for critical thinking of the sort Mbeki expressed without engaging him in a dialogue in which his only interlocutors were dissidents".

A recurring idea in my own reflection on these tensions has been the need to think more decisively concerning the place that social sciences can occupy and how anthropologists produce their own evidence in contexts like these. The issue of "evidence" is particularly sensitive in discussions on the scientificity of AIDS studies and appeared to be a key issue for the interlocutors most aligned with the scientific "orthodoxy" in South Africa. It refers to the broader question of how we know and how we construct our objects of knowledge. Engelke (2009) has suggested that reflection by anthropologists on the concept 
of evidence could provide them with a language through which to engage with colleagues from other humanities and natural sciences, as well as actors and groups of interest. However, it seems to me that some of the difficulties encountered by anthropology in this case, recalling the words of Elias (1956: 251), "....are due to insufficiencies not so much in the knowledge of facts, as in the basic ideas, categories and attitudes used in making observations of, and in handling, facts". Disagreements within a discipline or within a field of knowledge often depend on what counts as evidence and the criteria for judging the same.

Moreover, despite the strength of the calls for "evidence-based medicine", so present in the discussions on AIDS in South Africa (see Geffen 2010; Nattrass 2007; 2012), it is worth remembering the position of UNAIDS itself $(2015$, p. 7$)$ concerning such notions as "evidence" and "evidence-based".

In the context of research, treatment and prevention, evidence usually refers to qualitative and/or quantitative results that have been published in a peer-reviewed journal. The preference for evidence-informed is in recognition of the fact that several elements may play a role in decision-making, only one of which may be scientific evidence. Other elements may include cultural appropriateness, concerns about equity and human rights, feasibility, opportunity costs and so on.

It is plausible that the discomfort manifest by some of Mbeki's critics and advocates of "AIDS science" when faced with anthropological reflections has much less to do with how these reflections resemble the arguments of the then president than with the structural tension of relations in the intellectual field of AIDS. From a more general point of view, such criticisms of anthropology could be understood in the light of the hegemony that the "naturalistic worldview" imposes on polemics that, like the discussion on AIDS, are situated "on the boundary of modern naturalism" as proposed by Duarte (2004). According to the author, such polemics bring to light "contemporary naturalistic reductionisms" as reiteration of the Enlightenment ideal of science. The AIDS debate in South Africa is an exemplary expression of the "founding tension" between the Enlightenment and Romanticism in the formation of modern Western thought and points to a discussion of the epistemological configuration of the "native cosmology of the West".

In an environment where the "politicisation of science" has been denounced repeatedly and its autonomy vindicated, the entreaty of doctors, scientists and activists for "evidence-based HIV programs" raises questions concerning the "scientific governance of medicine". Likewise, the opposition that is created, based on this entreaty, between "biomedicine" and "alternative therapies" and between "science" and "pseudoscience" or "quackery" challenges anthropological reflections on systems of knowledge and cultural diversity. If, in the context of South African discussions on AIDS, anthropology becomes the object of suspicion and even rejection because it supposedly supports "denialism", rationalizing it, justifying it, instead of "combating it", perhaps this fact does nothing more than update the habitual difficulty of ethnographic research and the conflicting relationships that historically an important part of anthropology conducted in South Africa has waged with official knowledge (see e.g. Waal \& Ward, 2007). However, this situation raises a new challenge: how can anthropological knowledge contribute to a greater understanding of the dissensions and the possibilities of consensuses, especially when from the "native" perspective, the disputes seem insurmountable?

What its critics in South Africa seem to question is, after all, the commitment of anthropologists to this part of the country's recent history and the relevance of anthropological knowledge to the HIV epidemic. However, not even their most bitter critics can say that anthropologists in South Africa deny that HIV causes AIDS or question the use of antiretroviral therapies as the best treatment currently available. On the other hand, the denunciation of the alleged relativistic approach of anthropologists and their 
detrimental effects at a time when the rallying cry is "saving lives" seems to neglect that discussions on "relativism", "essentialism", "diversity", etc., are as old as the discipline of anthropology itself and form part of a centuries-old tension in the South African case. Perhaps a more accurate means for anthropological intervention in environments so refractory to its contributions is, in the wake of the successful treatment literacy programme sponsored by the TAC, to provide critics of the discipline with a sort of anthropological literacy.

Translated by Philip S P Badiz

Submitted: September 18, 2015

Approved: April 12, 2016

\section{References}

BASTOS, Cristiana. 2002. Ciência, poder, aç̧ão: as respostas à SIDA. Lisboa: Imprensa de Ciências Sociais, Instituto de Ciências Sócias da Universidade de Lisboa.

BECKER, Howard. 2008. Outsiders: studies in the sociology of deviance. New York: Free Press.

BERGER, Jonathan M. \& KAPCZYNSKI, Amy. 2009. "The story of the TAC Case: the potential and limits of socio-economic rights litigation in South Africa”. In: Deena R. Hurwitz \& Margaret L. Satterthwaite (eds.), Human rights advocacy stories. New York: Thomson Reuters/Foundation Press. pp. 43-79.

BIBEAU, Gilles \& MURBACH, Ruth. 1991. "Présentation. Déconstruire l'universe du sida”. Anthropologie et Sociétés, 15(2-3): 5-11.

BOLTANSKI, Luc. 1984. "La denónciation". Actes de la Recherche en Sciences Sociales, 51(1):3-40. . 1993. "La topique de la dénonciation”. In: La souffrance à distance: morale humanitaire, médias et politique. Paris: Métailie. pp. 91-116.

_. \& THEVENOT, Laurent. 1991. De la justification: les économies de la grandeur. Paris: Gallimard.

BRANDON F.; KEELE et al. 2006. "Chimpanzee resevoirs of pandemic and nonpandemic HIV-1". Science, 313(5786):523-526.

CALDWELL, John C. \& CALDWELL, Pat. 2003. "The African AIDS epidemic. HIV: 20 years of research.” Scientific American Exclusive online issue. http://cbc.arizona.edu/classes/bioc461/HIV-AIDS-References/ The\%20African\%20AIDS\%2oEpidemic.pdf Acessed on: 30 May, 2016.

CAMARGO, Kenneth Rochel de. 1994. As ciências da AIDS e a AIDS das ciências. O discurso médico e a construção da AIDS. Rio de Janeiro: ABIA/IMS-UERJ/Relume Dumará.

CAMERON, Edwin. 2005a. Witness to AIDS. New York: I.B. Tauris. . 2005b. Legal and human rights responses to the HIV/AIDS epidemic. Special Lecture at Faculty of Law, Stellenbosch University. Mimeo.

CLATTS, R. Michael; DEREN, Sherry \& TORTU, Stephanie. 1991. "What's in a name? La construction sociale du risque du sida chez les consommateurs de drogue à Harlem". Anthropologie et Sociétés, 15(2-3):37-52.

CLOETE, Michael. 2007. “The colour of AIDS”. South African Journal of Philosophy, 26(4):388-402.

DAS, Veena \& POOLE, Deborah (editors). 2004. Anthropology in the margins of the State: comparative ethnographies. Santa Fe: James Currey/School of American Research Press. 
DUARTE, Luis Fernando Dias. 2004. “A pulsão romântica e as ciências humanas no Ocidente”. Revista Brasileira de Ciências Sociais, 19(55):5-19.

ECO, Umberto. 2012. Inventing the enemy and other occasional writings. Boston, New York: Houghton Mifflin Harcourt.

ELIAS, Norbert. 1956. "Problems of involvement and detachment". The British Journal of Sociology, 7(3):226252.

ENGELKE, Matthew E. (editor). 2009. The objects of evidence. Anthropological approaches to the production of knowledge. Malden, MA, USA; Oxford and West Sussex, UK: Wiley-Blackwell \& RAI.

FARMER, Paul. 2006. AIDS \& accusation. Haiti and the geography of blame. Updated with a new preface. Berkeley, Los Angeles (CA) \& London: University of California Press.

FASSIN, Didier. 2007. When bodies remember: experiences and politics of AIDS in South Africa. Berkeley: University of California Press.

\& SCHNEIDER, Helen. 2003. "The politics of AIDS in South Africa: beyond the controversies". British Medical Journal, 326:495-497.

FELDMAN, Allen. 2002. "Strange fruit: the South-African Truth Commission and the demonic economies of violence". In: Bruce Kapferer (editor), Beyond rationalism: rethinking magic, witchcraft and sorcery. NY| Oxford: Berghahn Books. pp. 234-265.

FERGUSON, James. 2006. "Introduction: global shadows; and globalizing Africa? Observations from an inconvenient continent". In: Global shadows. Africa in the neoliberal world order. Durham \& London: Duke University Press. pp. 1-49.

FLECK, Ludwik. 1979. Genesis and development of a scientific fact. Chicago/London: The University of Chicago Press.

GEFFEN, Nathan. 2010. Debunking delusions: the inside story of the treatment action campaign. Auckland Park: Jacana Media.

GEVISSER, Mark. 2009. Thabo Mbeki: the dream deferred (Updated International Edition). Johanesburg \& Cape Town: Jonathan Ball.

GILBERT, M. Thomas P et al. 2007. The emergence of HIV/AIDS in the Americas and Beyond. Proceedings of the National Academy of Sciences. http://www.pnas.org/content/104/47/18566.full.pdf+html. Accessed on: $12^{\text {th }}$ May, 2009.

GILKS, Charles F. 1991. "What use is a clinical case definition for AIDS in Africa?". British Medical Journal, 303:1189-119o.

GOLIBER, Thomas. 2002. The status of the HIV/AIDS epidemic in Sub-Saharan Africa. Population Reference Bureau. http://www.prb.org/Articles/2002/TheStatusoftheHIVAIDSEpidemicinSubSaharanAfrica.aspx. Accessed on: $12^{\text {th }}$ April, 2009 .

GREEN, Lesley JF. 2012. "Beyond South Africa's 'indigenous knowledge - science' wars". South African Journal of Science, 108(7/8), Art. \# 631, $10 \mathrm{p}$.

HERWITZ, Daniel. 2006. “Sida, savoir et réinvention de la société civile en Afrique du Sud”. Politique Africaine, 3(103): 46-60.

HERZFELD, Michel. 2004. "The practice of stereotypes". In: Cultural intimacy: social poetics in the NationState. London: Routledge. pp. 201-210.

HEYWOOD, Mark. 2003. "Preventing mother-to-child HIV transmission in South Africa: background, strategies and out-comes of the treatment action campaign case against The Minister of Health". South African Journal of Human Rights, 19: 278-315. 
2004. "The price of denial". Interfund Development Update, 5(3): 93-122.

HYDE, Sandra Teresa. 2008. "Everyday AIDS practices. Contestations of borders and infectious disease in Southwest China”. In: Mary-Jo Del Vecchio Good; Sandra T. Hyde; Sarah Pinto \& Byron J. Good (eds.), Postcolonial disorders. Berkeley, Los Angeles, London: University of California Press. pp. 189-217.

KALICHMAN, Seth C. 2009. Denying AIDS. Conspiracy theories, pseudocience, and human tragedy. New York: Springer.

KEOU, F. X. et al.. 1992. "World Health Organization clinical case definition for AIDS in Africa: an analysis of evaluations". East African Medical Journal, 69(10): 550-553.

MANN, Jonathan \& TARANTOLA, Daniel. 1998. "Responding to HIV/AIDS: a historical perspective". Health and Human Rights, 2(4):5-8.

MARQUES, Maria Cristina da Costa. 2005. "Contradições e assimetrias na construção do conhecimento em AIDS/HIV”. História, Ciências, Saúde - Manguinhos, 12(2): 575-579.

MBALI, Mandisa. 2004. "AIDS discourses and the South African State: government denialism and postapartheid AIDS policy-making”. Transformation: Critical Perspectives on Southern Africa, 54: 104-122.

MBEMBE, Achille. 2000. "At the edge of the world: boundaries, territoriality, and sovereignty in Africa". Public Culture, 12(1): 259-284.

MCGREAL, Chris. 2007. "Mbeki admits he is still AIDS dissident six years on". The Guardian, o6 November. MYBURGH, James. 2007. The African National Congress under the presidency of Thabo Mbeki (1997/2002). St. Antony's College (University of Oxford), Thesis (D. Phil., Politics and International Relations).

NATTRASS, Nicoli. 2007. Mortal combat. AIDS denialism and the struggle for antiretrovirals in South Africa. Scottsville: University of KwaZulu-Natal Press. . 2012. The AIDS conspiracy: science fights back. Johannesburg: Wits University Press.

PEPIN, Jacques. 2011. The origins of AIDS. New York: Cambridge University Press.

POLLAK, Michael \& SCHILTZ, Marie-Ange. 1987. "Identité sociale et gestion d'un risqué de santé. Les homosexueles face au sida". Actes de la Recherche en Sciences Sociales, 68:77-102.

. 1991. "Les homosexuals français face au sida. Modifications des pratiques sexuelles et émergence de nouvelles valeurs". Anthropologie et Sociétés, 15(2-3): 53-62.

RAMIN, Brodie. 2007. "Anthropology speaks to medicine: the case HIV/AIDS in Africa". McGill Journal of Medicine, $10(2): 127-132$.

ROBINS, Steven. 2004. “'Long live Zackie, long live': AIDS activism, science and citizenship after Apartheid". Journal of Southern African Studies, 30(3): 651-672.

----- 2011. "TAC film opens space for debate". Cape Times, $18^{\text {th }}$ October, p. 11.

SAYAD, Abdelmalek. 1991. L'immigration ou les paradoxes de l'altérité. Bruxelles: De Boeck Université; Paris: Universitaires.

SCHNEIDER, Helen \& FASSIN, Didier. 2002. "Denial and defiance: a socio-political analysis of AIDS in South Africa”. AIDS, 16 (suppl 4): S45-S51.

SCHOEPF, Brooke G. 2001. "International AIDS research in anthropology: taking a critical perspective on the crisis". Annual Review of Anthropology, 30: 335-361.

SHANNON, Gary W. 1991. "A search for origins". In: Richard Ulack \& William F. Skinner (ed.), AIDS and the social sciences. Common threads. Lexington, KY: The University Press of Kentucky. pp. 8-29.

SITZE, Adam. 2004. "Denialism". The South Atlantic Quarterly, 103(4): 769-811.

SÍVORI, Horacio Federico. 2007. Ativistas e peritos no movimento GLTTB-AIDS argentino: ciência e política da identidade sexual. Tese de doutorado, Rio de Janeiro, Programa de Pós-Graduação em Antropologia Social, Universidade Federal do Rio de Janeiro. 
STEIN, Rob. 2007. “Scientists track time and place of HIV's arrival". The Washington Post, Monday, November 5, p. A10.

STEPHENSON, Peter H. 1991. "Le sida, la syphilis et la stigmatisation. La genèse des politiques et des préjugés”. Anthropologie et Sociétés, 15(2-3): 91-104.

TIMBERG, Craig. 2006. "How AIDS in Africa was overstated". The Washington Post, o6 April 2006.

UNAIDS. 2013. Global report: UNAIDS report on the global AIDS epidemic 2013. Geneva: Joint United Nations Programme on HIV/AIDS (UNAIDS).

UNAIDS. 2015. UNAIDS terminology guidelines. Geneva: Joint United Nations Programme on HIV|AIDS (UNAIDS).

EPIDEMIAS. 2009. Epidemias: a humanidade em perigo. Doenças que quase exterminaram o homem em diferentes momentos da história. São Paulo: Escala.

WAAL, Kees (C. S.) van der \& WARD, Vivienne. 2007. "Introduction to anthropology Southern Africa, special edition on 'Debating Southern African Anthropology'”. Anthropology Southern Africa, $30(3$ \& 4): $67-74$.

Guillermo Vega Sanabria

Department of Social Science, Federal University of Viçosa, Viçosa/MG, Brazil vegasanabria@gmail.com 